\title{
Amorphous Phase Mediated Crystallization: Fundamentals of Biomineralization
}

\author{
Wenjing Jin ${ }^{1,2}$, Shuqin Jiang ${ }^{3}$, Haihua Pan ${ }^{1, *}$ (1) and Ruikang Tang ${ }^{2, *}$ \\ 1 Qiushi Academy for Advanced Studies, Zhejiang University, Hangzhou 310027, China; panhh@zju.edu.cn \\ 2 Department of Chemistry and Centre for Biomaterials and Biopathways, Zhejiang University, \\ Hangzhou 310027, China \\ 3 School of Public Health, Department of Toxicology, Capital Medical University, Beijing 100069, China; \\ jshuqin@ccmu.edu.cn \\ * $\quad$ Correspondence: panhh@zju.edu.cn (H.P.); rtang@zju.edu.cn (R.T.); Tel.: +86-571-8795-3736 (H.P.); \\ $+86-571-8795-1352$ (R.T.)
}

Received: 18 December 2017; Accepted: 11 January 2018; Published: 19 January 2018

\begin{abstract}
Many biomineralization systems start from transient amorphous precursor phases, but the exact crystallization pathways and mechanisms remain largely unknown. The study of a well-defined biomimetic crystallization system is key for elucidating the possible mechanisms of biomineralization and monitoring the detailed crystallization pathways. In this review, we focus on amorphous phase mediated crystallization (APMC) pathways and their crystallization mechanisms in bio- and biomimetic-mineralization systems. The fundamental questions of biomineralization as well as the advantages and limitations of biomimetic model systems are discussed. This review could provide a full landscape of APMC systems for biomineralization and inspire new experiments aimed at some unresolved issues for understanding biomineralization.
\end{abstract}

Keywords: biomineralization; crystallization; amorphous calcium phosphate; amorphous calcium carbonate; nucleation

\section{Introduction}

Biomineralization is a crystallization process that occurs in a biological environment and is controlled by biological systems [1-3]. The biological micro-environments, such as the supersaturated mineralization medium, the extracellular matrixes (ECMs), and non-matrix proteins (NMPs) of biomineralization systems, play key roles in controlling the crystallization using hierarchical ordered structures, complicated patterns, and morphology. Calcium phosphate $(\mathrm{CaP})$ and calcium carbonate $(\mathrm{CaC})$ crystals are predominant inorganic components of biominerals in vertebrates and invertebrates. Moreover, amorphous calcium carbonate is also found in plants (cystoliths) [4-7]. The investigation of their crystal nucleation and growth in a biomimetic micro-environment is critically important for understanding the mechanism of biomineralization. Classical crystallization theories have been widely applied for understanding the crystallization behavior of biomimetic mineralization systems [3,8,9]. However, recent studies have failed to adequately explain many biomimetic crystallization systems using classical crystallization theory [10-12], which supposes that crystal nucleation or growth is formed directly from ion-by-ion additions [13]. Recently, researchers began hypothesizing that varied "nonclassical" crystallization pathways were more likely to be a product of biomineralization (Figure 1) [14], which refers to aggregation-based crystallization [15,16], pre-nucleation clusters [17-20], and amorphous phase mediated crystallization (APMC) [21-24]. Among these, the findings of the amorphous phase in biomineralization systems are well documented [21,23-26], but the crystallization mechanism remains largely unknown. 


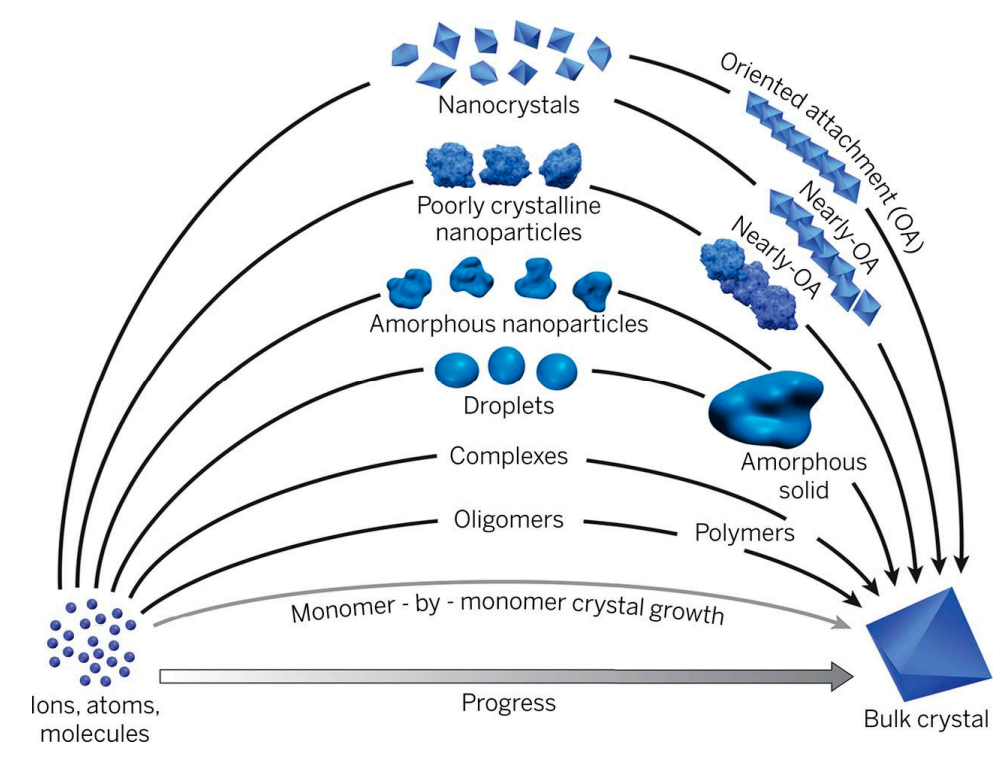

Figure 1. Schematic elucidation of classical (monomer-by-monomer crystal growth) and "nonclassical" crystallization pathways. Reproduced with permission from the American Association for the Advancement of Science in Reference [14].

$\mathrm{CaP}$ and $\mathrm{CaC}$ crystallization systems are two representative model systems for biomineralization which have attracted extensive attention. Amorphous calcium phosphate (ACP) was found to be the precursor for hydroxyapatite (HAP) crystallization in bio- [25,27-29] and biomimetic [10,20,30-34] $\mathrm{CaP}$ mineralization systems. Amorphous calcium carbonate (ACC) is the precursor phase for many invertebrate biomineralizations, such as in the formation of sea urchins [35,36], mollusk shells [23,37-39], and coral skeletons [40]. The transformation of amorphous phases to crystalline phases (Table 1) can occur via several crystallization pathways [21,24,41-45], such as surface-mediated heterogeneous nucleation [11,46-48], dissolution/re-precipitation [49-56], and solid-solid phase transformation (structure reorganization) [19,33,57-62]. The transformation mechanism and crystallization kinetics depend vitally on the detailed crystallization pathway and on the solution environment [52]. Many controversial results have surfaced regarding these systems [19,52]. So, it is urgent to know the full landscape of the crystallization rules of amorphous mediated crystallization systems and how to regulate the crystallization pathways and their kinetics, which are fundamental for understanding biomineralization.

In this review, we pay special attention to $\mathrm{CaP}$ and $\mathrm{CaC}$ systems, but we will summarize the findings of the APMC pathways in bio- and biomimetic mineralization systems and the detailed crystallization pathways, as well as transformation kinetics and their influence on biomineralization.

\section{Amorphous Phase-Mediated Crystallization Pathways in Bio- and Biomimetic Mineralization Systems}

\subsection{Biomineralization Systems}

In matured products of biomineralization such as vertebrate bones and teeth, mollusk shells, coral skeletons, coccolith exoskeletons, and magnetotactic bacteria magnetosomes, the primary inorganic composition of biominerals is the crystallized mineral [1,2,63]. It has taken several decades of effort for researchers to confirm the first-formed mineral phase in many biomineralization systems. Take vertebrate bone formation as an example. In 1966, Termine et al. reported that ACP is a major component of bone mineral in the femurs of male rats at the initial stages of bone formation [27]. During bone formation, the amount of ACP decreased in the bone, while the crystalline apatite increased, suggesting that $\mathrm{ACP}$ was the precursor phase for bone formation. It was not until 2008 
that Mahamid et al. conclusively confirmed that ACP was the precursor phase by temporally and spatially resolved mapping of the transformation of ACP in crystalline minerals in zebrafish fin rays (Figure 2) [64]. Boonrungsimana et al. revealed that ACP can be formed within osteoblast mitochondrial granules and intracellular vesicles and then transported to the extracellular collagenous matrix for bone formation [65]. ACP was also found to be the precursor phase of the carbonated apatite in vertebrate enamel [66]. Some invertebrates also use ACP as the precursor phase during biomineralization. For example, some invertebrates use the radular teeth of a chiton (Acanthopleura haddoni, [67]), or the bivalved shell of extant Linguliform brachiopods (Lingula anatina) for the precursor phase of biomineralization [68].

Table 1. Chemical formulae and solubility of common phosphate and carbonate minerals.

\begin{tabular}{|c|c|c|}
\hline Phase & Formula & Solubility $^{a}-\log \left(K_{s}\right)$ \\
\hline Dicalcium phosphate dihydrate (DCPD) ${ }^{b}$ & $\mathrm{CaHPO}_{4} \cdot 2 \mathrm{H}_{2} \mathrm{O}$ & 6.59 \\
\hline Octacalcium phosphate $(\mathrm{OCP})^{\mathrm{b}}$ & $\mathrm{Ca}_{8}\left(\mathrm{HPO}_{4}\right)_{2}\left(\mathrm{PO}_{4}\right)_{4} \bullet 5 \mathrm{H}_{2} \mathrm{O}$ & 96.6 \\
\hline$\alpha$-Tricalcium phosphate $(\alpha-\mathrm{TCP}) \mathrm{b}$ & $\alpha-\mathrm{Ca}_{3}\left(\mathrm{PO}_{4}\right)_{2}$ & 25.5 \\
\hline$\beta$-Tricalcium phosphate $(\beta$-TCP) $b$ & $\beta-\mathrm{Ca}_{3}\left(\mathrm{PO}_{4}\right)_{2}$ & 28.9 \\
\hline Hydroxyapatite (HAP) ${ }^{b}$ & $\mathrm{Ca}_{10}\left(\mathrm{PO}_{4}\right)_{6}(\mathrm{OH})_{2}$ & 116.8 \\
\hline Vaterite $^{\mathrm{c}}$ & $\mathrm{CaCO}_{3}$ & 7.91 \\
\hline Aragonite $^{\mathrm{c}}$ & $\mathrm{CaCO}_{3}$ & 8.34 \\
\hline Calcite $^{\mathrm{c}}$ & $\mathrm{CaCO}_{3}$ & 8.48 \\
\hline
\end{tabular}

${ }^{a}$ The solubility is given as the logarithm of the ion product of the given formulas. ${ }^{b}$ Data from Reference [24]. ${ }^{\mathrm{c}}$ Data from Reference [69].
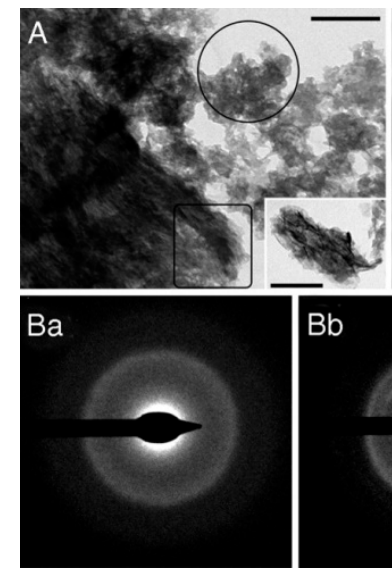

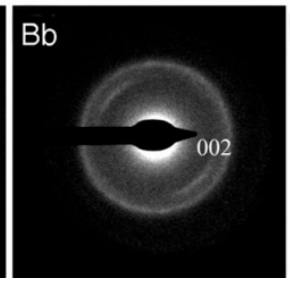

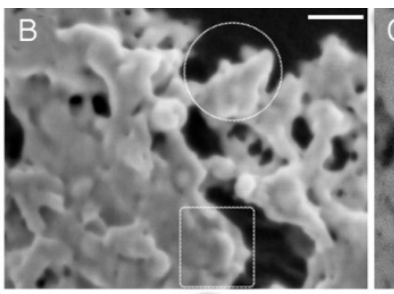

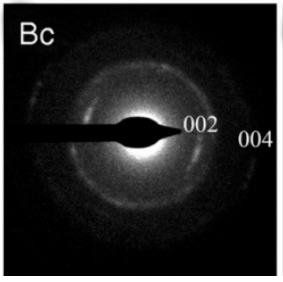

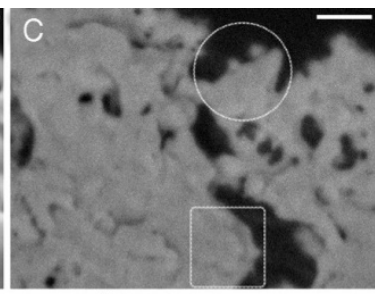

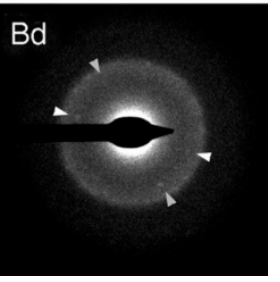

Figure 2. TEM and selected area electron diffraction patterns (SAED) correlated with SEM and energy selective backscattered (ESB) imaging of mineral freshly extracted from the distal end of the fin. (A and B.a-B.d) TEM micrograph of mineral particle aggregates and the corresponding SAED patterns: encircled particle produces amorphous scatter of diffuse rings (SAED, B.a). Area marked with a rectangle produces poorly crystalline diffraction (SAED, B.b), and particle in Inset produces a clear crystalline diffraction pattern (SAED, B.c), showing well defined reflections of the (002) and second order (004) apatite planes. (SAED B.d), corresponds to the encircled area examined after storage for 1 week at room temperature: As the particles begin to crystallize, diffraction spots with spacing of the (002) plane appear (arrowheads), implying conversion into a crystalline apatite phase. (B) High-resolution cryo-SEM micrograph of the same particle, uncoated, taken after examination in the TEM. (C) Corresponding ESB image, showing no distinguishable difference between the signal intensity of the amorphous (encircled area) and crystalline (rectangular area) mineral parts. (Scale bars $100 \mathrm{~nm}$.) Reproduced with permission from Reference [64] Copyright (2008) National Academy of Sciences, U.S.A. 
For the $\mathrm{CaC}$ biomineralization system, the presence of the ACC precursor phase was frequently found and was generally considered a smart strategy in nature for producing biominerals with unique shapes and advanced hybrid structures $[23,25,70]$. Politi et al. showed that the regeneration process of sea urchin spine is completed via the initial deposition of amorphous calcium carbonate and then ACC is phase transformed into calcite (Figure 3) [35,36]. Mass et al. used direct photoemission electron spectromicroscopy (PEEM, PEEM-3 at the Advanced Light Source in Berkeley, CA, USA.) and X-ray absorption near-edge structure spectroscopy evidence in Stylophora pistillata corals to show that two amorphous precursors existed, including one hydrated and one anhydrous ACC [40]. This work reveals two advantages of ACC-mediated crystallization. First, the crystallization via ACC is more than 100 times faster than the classical ion-by-ion crystallization. Second, ACC particles are formed inside tissue, which may make coral skeleton formation less susceptible to ocean acidification and help the coral skeleton formation survive during $\mathrm{CO}_{2}$ increases. Weiss et al. showed that, in mollusk larvae, ACC was the precursor phase that partially transformed into aragonite [71]. The use of a transient amorphous precursor appears to be a widespread phenomenon in biomineralization.

However, biological systems are too complex in terms of crystallization, and it is still a challenge to measure the exact microenvironment of the intracellular and extracellular biomineralization cells and to detect the detailed crystallization pathways. Detecting these pathways is vitally important for understanding the mechanisms of biomineralization. In vitro biomimetic mineralization systems are designed to tackle this problem.
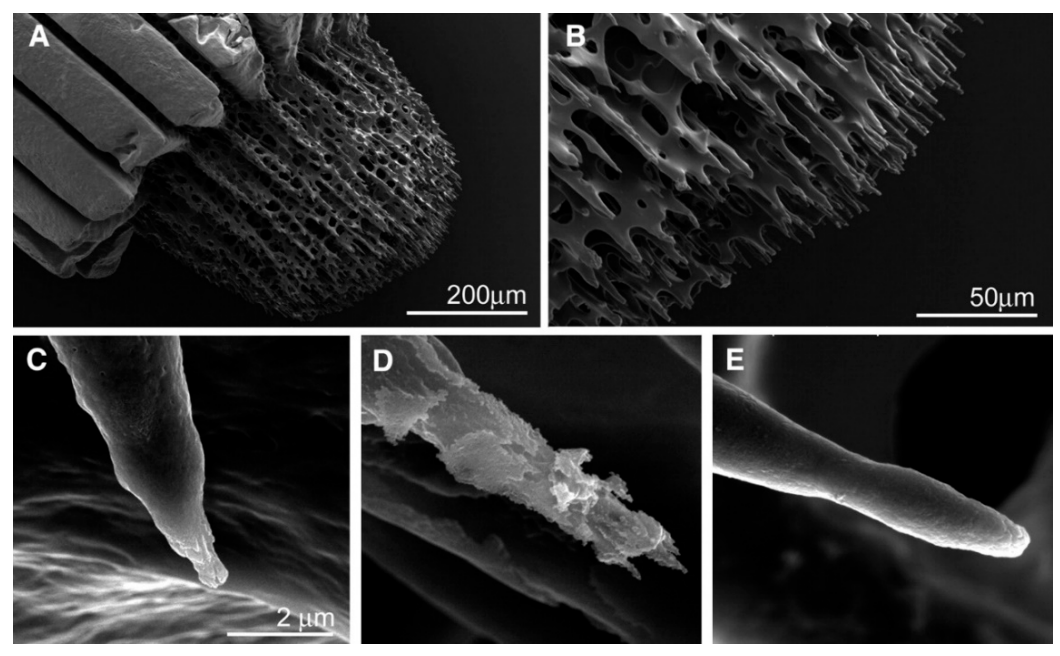

Figure 3. Scanning electron micrographs of regenerating sea urchin spines. (A) Five-day-old regenerated spine growing on the original broken spine. (B) Higher magnification view of the tip of the new growth, showing the typical stereom structure and the protruding newly formed microspines. (C) One microspine formed after 4 days of regeneration, observed fresh. (D) Four-day-old microspine, etched in water while fresh. (E) Four-day-old microspine, etched in water 1 month after regeneration. The newly formed tip showing the typical stereo structure of spines. Further characterization indicated that the minerals removed from fresh regenerated spines were amorphous calcium carbonate. Reproduced with permission from the American Association for the Advancement of Science in Reference [36].

\subsection{Biomimetic Mineralization Systems}

Biomimetic mineralization experiments have been successful in reproducing the morphology of biominerals. These experiments have uncovered the detailed crystallization behavior in conditions similar to those in biomineralization systems. Biomimetic mineralization has well-defined experimental conditions, and the detailed crystallization process can be monitored and quantified. So, it is a good testing board to validate the possible mechanism of biomineralization and to detect the detailed 
crystallization pathways. In terms of crystallization, a biomineralization process can be regarded as crystallization held at the self-assembled matrix and constraint space controlled by biomolecules in a medium of supersaturated solutions. All these factors have been investigated in detail by biomimetic mineralization.

\subsubsection{Mineralization Medium}

First, we summarize the recipes which have been used for biomimetic mineralization medium. To mimic a solution medium of bone formation, Kokubo et al. introduced a solution with ion concentrations close to that of human blood plasma (HBP), called simulated body fluids (SBF) [72-74]. SBF are near saturated or slightly supersaturated solutions with respect to ACP, and highly supersaturated with respect to HAP $[61,75,76]$. SBF have been successful in generating a bone-like apatite layer on the surface of Bioglass-ceramic and Titania bone-implant materials to endow their capability of direct bonding to living bone [73]. When HAP particles were soaked in an SBF solution, $\mathrm{ACP}$ was first precipitated on their surface and then transformed into bone-like apatite [77]. In original SBF solution, the concentration of calcium and phosphate is relatively low, and the capacity for the precipitation of $\mathrm{CaP}$ minerals is limited. In practical applications, the calcium and phosphate concentrations were increased to precipitate more $\mathrm{CaP}$ minerals (e.g., $1.5 \times \mathrm{SBF}, 5 \times \mathrm{SBF}$, or others) with a neutral $\mathrm{pH}$ and $0.15 \mathrm{M}$ ionic strength [78-81]. With increasing calcium and phosphate concentrations, the formation of the ACP precursor phase is more evident. In the absence of substrates, ACP particles in the solution can also be transformed into HAP $[10,48,58,59,82]$. Posner et al. proposed that the transformation process is conducted via the dissolution of ACP and crystallization of HAP from the solution $[49,51,83]$. However, ex-situ TEM observations supported that HAP initially nucleated on the surface of ACP particles, which was probed by the mark of gold nanoparticles (Figure 4) [82] or by a direct observation of the evolution of ACP transformation [48]. The quantitative study of the nucleation kinetics also fit the model of ACP surface-mediated heterogeneous nucleation $[10,11]$. The surface area of ACP and the activity of calcium ions in solution are the key factors for controlling nucleation kinetics [6,7]. Citrate [84], poly-Asp [11], silicate [85], solution $\mathrm{pH}$ [10], and the aggregation stated of ACP [86] can either modify the ACP surface or the surface area or change the activity of calcium in solution that leads to the inhibition or promotion of ACP phase transformation. In addition to the surface-mediated nucleation pathway, ACP-HAP crystallization might also go through other pathways, such as multiple sites nucleation inside ACP [58], HAP nucleation at ACP inter-particles boundary [87], and structure-rearrangement of the $\mathrm{Ca}_{9}\left(\mathrm{PO}_{4}\right)_{6}$ unit (called Posner cluster) in ACP $[33,61]$, which indicate that the CaP crystallization pathway is solution chemical-sensitive.

Similar to SBF, artificial sea water (ASW) has been made to mimic the chemical environment of current or ancient seawater [88-90], in which the biomineralization of coral, coccolith, and mollusk occurs. The possible effects of ASW compositions on calcium carbonate crystallization [12,91-93] and shell formation in living species $[88,90,94]$ have been investigated in detail. Blue et al. [12] studied the transformation of ACC in calcium carbonate solutions, and found that the crystallization pathway, the polymorph selection, and the mineral composition were sensitive to the physical (stir or not) and chemical ( $\mathrm{Mg} / \mathrm{Ca}$, carbonate/Ca ratio) conditions, which cannot be explained by the classical thermodynamic equilibria of crystallization. This provides a new understanding of biomineralization where organisms might control the physical-chemical factors (such as local alkalinity, $\mathrm{pH}$, and supersaturation) during biomineralization to enable the precipitation of metastable phases with the unusual calcite compositions and textures that cannot be obtained by the classical crystal growth models. Purgstaller et al. [95] found that Mg-calcites formed via the transformation of an initial Mg-rich amorphous calcium carbonate (Mg-ACC) precursor exhibit significantly higher Mg contents (up to $20 \% \mathrm{Mg}$ ) compared to those formed directly from the solution, which can give a reasonable understanding of $\mathrm{Mg}$ enrichment in biological calcite. This finding indicates that the $\mathrm{Mg}$ content of biogenic calcite precipitates depends on the crystallization pathway and does not directly trace the chemical composition of the precipitating solution. 


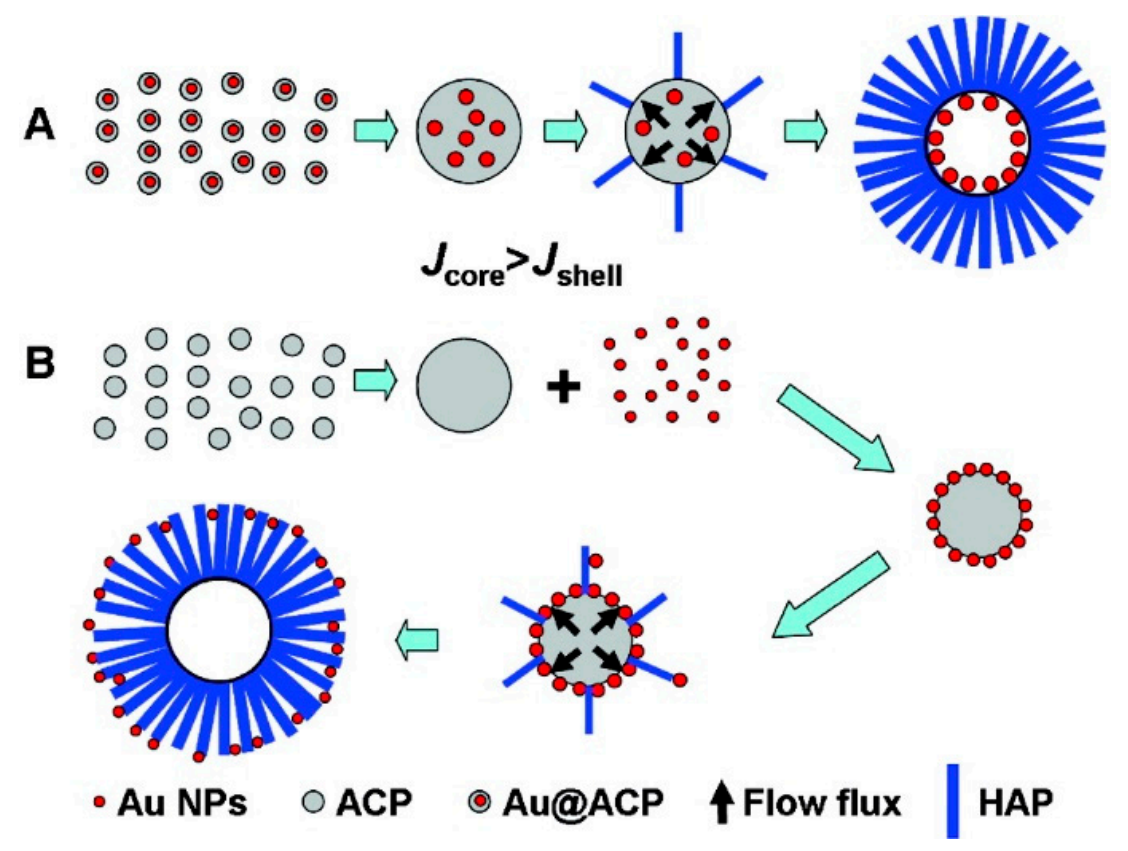

Figure 4. Schematic illustration of the evolution of amorphous calcium phosphate (ACP) probed by gold nano-particles (AuNPs) (A) for self-aggregation and Kirkendall process or (B) the surface of ACP sphere solution-mediated interface reaction. Reproduced with permission from the American Chemical Society in Reference [82].

\subsubsection{Biomimetic Organic Matrix}

Second, we summarize the investigations of the biomimetic organic matrix. The structures of the organic matrix in biomineralization systems always have the character of repeating units. For example, the matrix sheets of nacre composed of glycine- and alanine-rich proteins form beta-sheet conformation with structures similar to that of silk $[96,97]$. The bone matrix composition of collagen-I protein has repeating units of the GXY sequence, which form triple-helix nano-fibrils that can further be self-assembled into fibrils [98-101]. This kind of repeating unit pattern has been noted by structure biologists. Addadi and Weiner [102], Mann [103] first used extracted matrix macromolecules [102] or Langmuir films [103] to chemically mimic the structure of the biomatrix, and found the oriented crystallization of calcium carbonate crystals. These pioneering works directly revealed the stereochemical and molecular geometry template biomineralization models, which are milestones in the biomineralization community. Since then, the biomimetic study of calcium carbonate crystallization on ordered substrates has attracted attention. The later crystallizations of calcium carbonate on Langmuir films or self-assembled monolayers (SAM) provide many good examples of the template effect on oriented crystallization [69,104-107]. The template effect usually refers to the geometric or stereochemical match between a final crystal face and an organic matrix. However, the detailed crystallization pathway reveals the precursor phase that formed on the matrix, which is ACC $[19,56,108]$. This ACC-mediated crystallization pathway improved the understanding of biomineralization by simply using the structural template effect [38].

The demineralized organic matrix of biominerals is an excellent nature-made template. Gehrke et al. [109] retro-synthesized nacre layers by using the insoluble organic nacre matrix as the template (Figure 5). Oriented crystallization has been achieved, and after re-mineralization, it is difficult to differentiate between the retro-synthesized nacre and the natural one. The use of polymer-stabilized ACC as the precursor phase is key to successful retro-synthesis (otherwise, it fails). The demineralized bone or dentin matrix and the reconstructed collagen fibrils can guide the oriented crystallization of CaP. It was found that the presence of the highly charged polymer is 
vitally important to the successful oriented crystallization of apatite inside collagen fibrils. Charged polymers mimicking NMPs may make ACP precursors liquid-like (called polymer-induced liquid-like precursors, PILPs) [31] and highly-charged [110], or they may alter the osmotic pressure [111], which in the end facilitates ACP precursors to go inside collagen fibrils. Olstza et al. reported that with the PILP process [31], ACP precursors can be infiltrated into collagen fibrils. Nudelman et al. [110] further found that the positive net charge close to the C-terminal end of the collagen molecules is the initial site of mineralization, which was revealed by cryogenic transmission electron microscopy and cryogenic electron tomography. However, Niu et al. [111] proved that positively charged ACP can also infiltrate into the fibrils, and proposed that the polyelectrolyte might alter the osmotic pressure to facilitate the infiltration. Wang et al. [112] found that a high concentration of poly acrylic acid (PAA) $(500 \mu \mathrm{g} / \mathrm{mL}) \mathrm{can}$ stabilize ACP and inhibit the aggregation of amorphous clusters. As a result, amorphous clusters were found in dimensions of 1-2 nm. It was proposed that these nano-clusters go into the collagen fibrils and become the unit for later crystal growth of HAP. Almost all collagen mineralization systems introduce polymers to achieve the intrafibrillar mineralization, except one case reported by Wang et al. [113]. This work revealed that in the absence of any polymer, intrafibrillar mineralization can also be observed in dense fibrillar matrix $(250 \mathrm{mg} / \mathrm{mL}$; for comparison, most collagen stock solutions are just $5 \mathrm{mg} / \mathrm{mL}$ ) in an SBF solution. In this case, the ACP phase is still the precursor phase during collagen fibrils' mineralization. Currently, how the amorphous phase gets into the collagen fibrils and how it transforms into HAP inside collagen fibrils remain largely unknown. In situ TEM would be helpful for studying this process. However, it is still a challenge because the electron beam effect might damage collagen fibrils during observation.

The remineralization of dentin is of special interest for potential application in dentin repair. In comparison with reconstructed single-layer collagen fibrils on a TEM grid, the demineralized dentin matrix contains densely packed collagen fibrils, which are harder to fully re-mineralize. Many strategies have been developed to further promote the remineralization of dentin. Tay and co-workers have developed the strategies of collagen phosphorylation [114-116], silicified-collagen [117], and mesoporous silica carriers of ACP [118]. Tang and co-workers have found many small additives that promote the remineralization of dentin, such as glutamic acid [119] and glutaraldehyde [120].

The organic matrixes contain not only repeating units, but also hierarchical structure with nano-gaps inside the superstructures. This feature has attracted researchers' attention. The mechanism of nano-confinement has been proposed for better understanding of biomineralization, which revolves around the idea that competition for crystal growth in a confined space is sufficient to produce oriented crystallization [121-123]. The detailed micro-structural analyses showed the gradual ordering of crystallites as the growth of mollusks shells, which corroborated this mechanism. Gower and co-workers also considered that the oriented mineralization inside collagen fibrils could be controlled by nano-confinement [31]. Ping et al. [124] found the oriented crystallization of calcite inside collagen fibrils. The presence of PILP amorphous precursors are thought to play an important role in facilitating the infiltration of mineral precursors inside the nano-gap space before the crystallization. Some artificial confined spaces were built to test the effect of nano-confinement. Cantaert et al. [125] reported the oriented crystallization of calcium phosphate in nano-cylindrical pores that mimic collagen fibrils. Xiao et al. [126] morphosynthesized a biomimetic prismatic-type calcium carbonate layer on substrates with a granular transition layer through competing growths on films. The granular transition layer was formed on substrates using $\left(\mathrm{NH}_{4}\right)_{2} \mathrm{CO}_{3}$ gas diffusion into calcium solutions in the presence of poly-aspartic acid or poly-acrylic acid, in which amorphous precursors were formed as reported by Gower et al. [127]. Nacre-like structures were fabricated by using multilayered organic sheets as the scaffold, which can be produced using layer-by-layer assembly $[128,129]$ and freeze-casted laminated chitosan matrix [130]. The protocols that applied in these works to precipitate $\mathrm{CaC}$ are similar to those of PILP [127] and Xu's protocol [131], in which ACC is the precursor phase. 


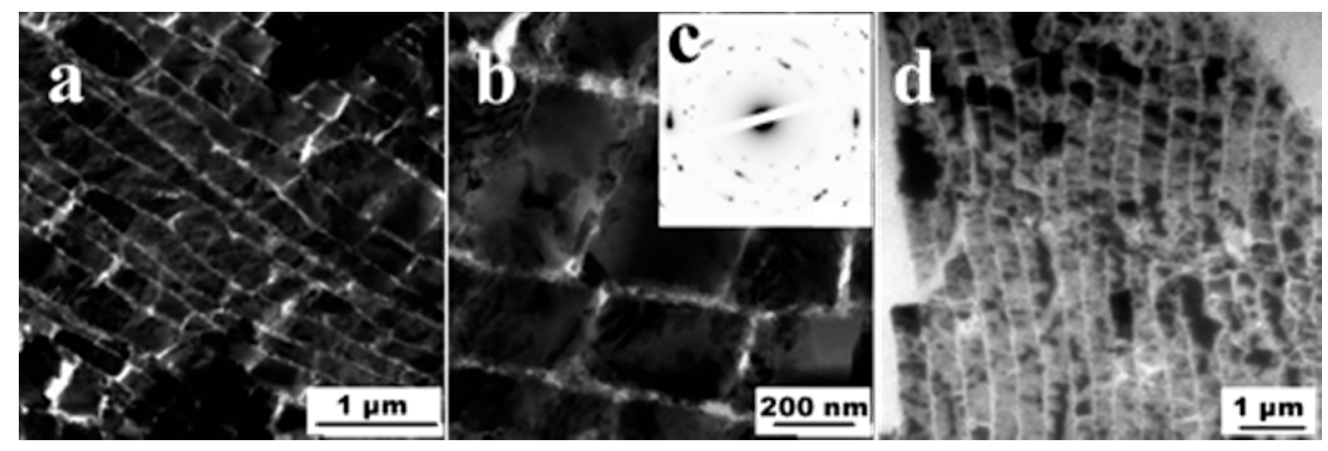

Figure 5. Using an insoluble organic nacre matrix as the template to retro-synthesize nacre layers. TEM micrographs of $(\mathbf{a}, \mathbf{b})$ of highly mineralized parts of synthetic nacre after $24 \mathrm{~h}$ reaction time. (c) Electron diffraction pattern of the platelets in panel b. (d) Original nacre from Haliotis laevigata. Reproduced with permission from the American Chemical Society in Reference [109].

In addition to inducing oriented crystallization, nano-confinement has many other effects on amorphous precursors worth noting for a more comprehensive understanding of biomineralization. Jiang et al. found that high-magnesium calcite formed from the confined crystallization of a Mg-ACC precursor [132]. Nanoscale confinement can also control the phase purity of minerals. A phase-pure bone-like apatite was formed in confinement with dimensions of less than $10 \mathrm{~nm}$ (confined in aqueous domains of polymerized liquid crystals) [133]. CaC crystals with complex morphologies were produced by transforming an ACC precursor within a defined constrained volume [134-136]. The amorphous phase was more stable when confined [137].

\subsubsection{Biomimetic Mineralization in the Presence of Non-Matrix Proteins and Their Analogues}

Lastly, the functions of NMPs and their analogues are discussed here. NMPs contain many charged groups, which are thought to play important roles in controlling crystallizations. For example, dentin matrix protein 1 (DMP1) and its functional domains controlled ACP-mediated HAP formation. The intermolecular assembly of acidic domains into a $\beta$-sheet template was essential for the mineral nucleation [138]. C-terminal fragments of DMP1 (C-DMP1) can promote collagen mineralization [111]. Fetuin can stabilize ACP and facilitate the penetration of CaP into the fibril, which leads to the successful intrafibrillar mineralization of collagen-I fibrils [110]. The function of NMPs can be mimicked by using polyelectrolytes, and they stabilize the amorphous precursors in a liquid-like state called PILP [21,127]. This can facilitate the infiltration of a precursor phase into the compartment of collagen fibrils (Figure 6) $[110,127,139]$ as well as artificial nano gaps as mentioned above. In the absence of the organic matrix, polyelectrolytes can also guide the formation of various hierarchically structured $\mathrm{CaP}$ and $\mathrm{CaC}$ crystals. Gower and co-workers have fabricated a variety of non-equilibrium (i.e., non-faceted) morphologies of minerals by using PILP as the precursor, including crystal drops [21], thin films/tablets [62,140,141], and fibers [142,143]. With the help of polyelectrolytes, Cölfen and co-workers have made varied $\mathrm{CaC}$ mesocrystals (superstructured nanocrystals with a common crystallographic orientation) (see the review of mesocrystals in biominerals [144]). A mesocrystal can be obtained by the oriented attachment of crystalline precursors [16,145-147]. However, the amorphous phase or poorly crystalline particles can also be the precursor phase for forming mesocrystals [148-150]. It should be noted that the exact crystallization pathway cannot be judged only by the mineral morphologies [14]. A critical analysis is needed to confirm the crystallization pathway [151]. 


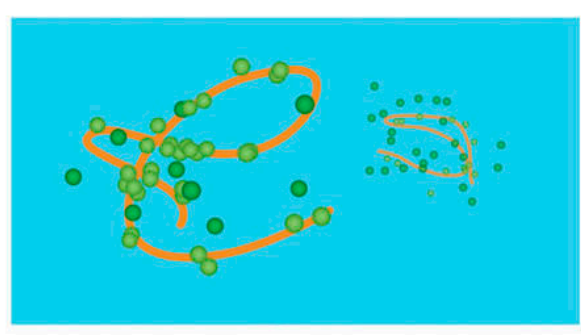

b

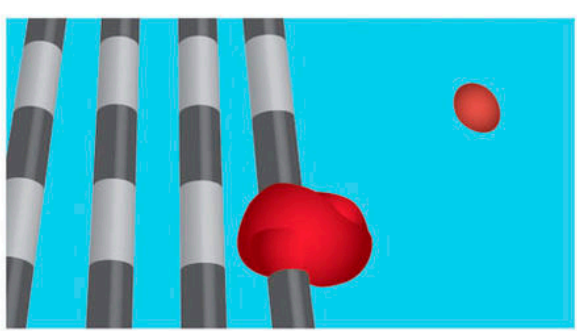

c

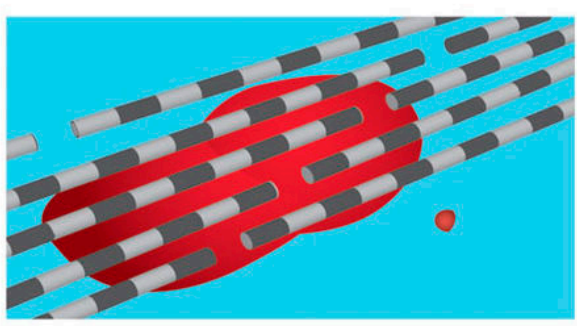

d

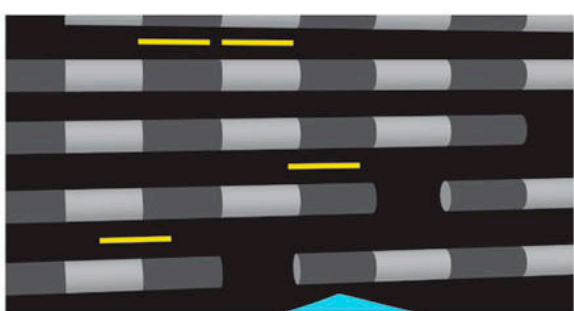

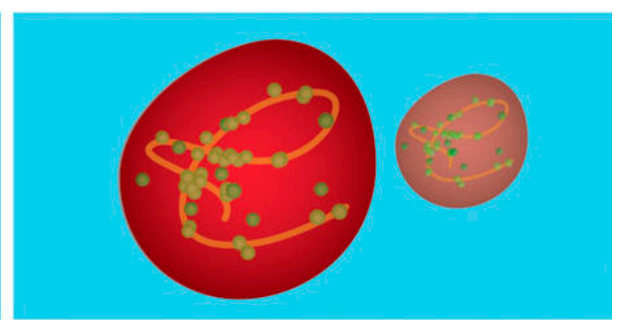
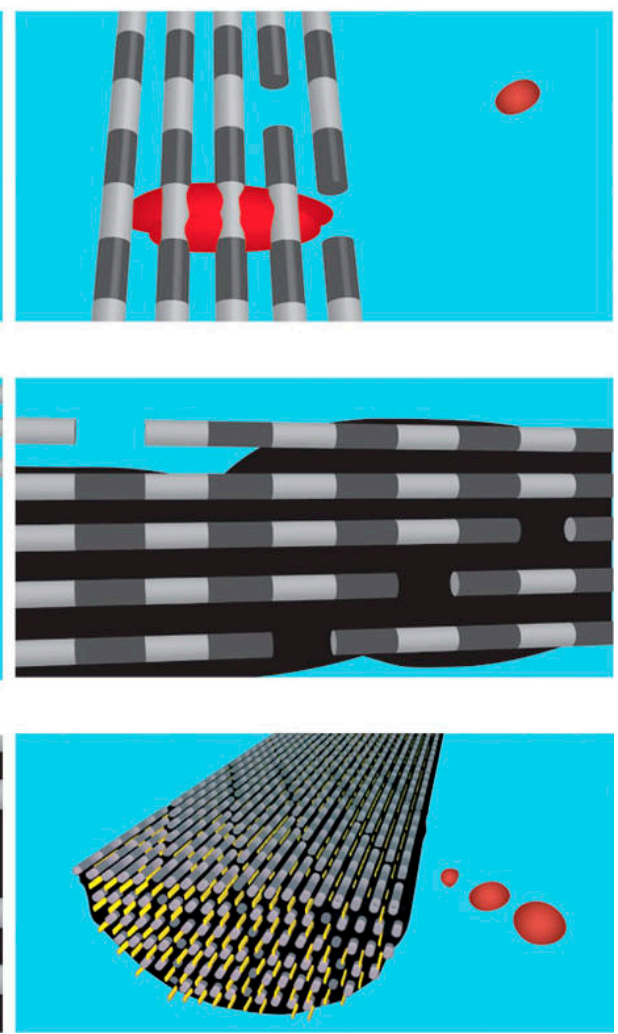

Figure 6. (a), Calcium phosphate clusters(green) form complexes with the polymer (orange line), forming stable mineral droplets. (b), Mineral droplets bind to a distinct region on the collagen fibres and enter the fibril. (c), Once inside the collagen, the mineral in a liquid state diffuses through the interior of the fibril and solidifies into a disordered(amorphous) phase (black). (d), Finally, directed by the collagen, the amorphous mineral transforms into oriented apatite crystals(yellow).Reproduced with permission from Springer Nature in Reference [139].

Instead of using polymers, many small charged biomolecules such as glutamic acid, aspartic acid (Figure 7), and surfactants can also mimic NMPs to control the aggregation of $\mathrm{CaP}$ and $\mathrm{CaC}$ precursors and form hierarchical biomineral-like structures. Through the control of the conglutination of HAP and ACP precursors with glycine and glutamic acid, enamel-like and bone-like apatite materials were obtained, respectively [152]. A bone-like or helical organic-CaP hybrid structure was developed in the presence of cetyl trimethylammonium bromide (CTAB) [153,154]. Although the precursor phase is still unknown in these systems, the compositions of mineralization solutions indicate that the initial solutions are supersaturated with respect to the ACP phase. In the presence of N-stearoyl-L-glutamic acid (C18-Glu), a mesocrystal-like calcite was obtained via amorphous or poorly crystalline CaC [150].

Clearly, the presence of NMPs and their analogues facilitate the formation of biomineral-like hierarchical structures, which would be helpful for understanding the possible pathways of biomineralization. 

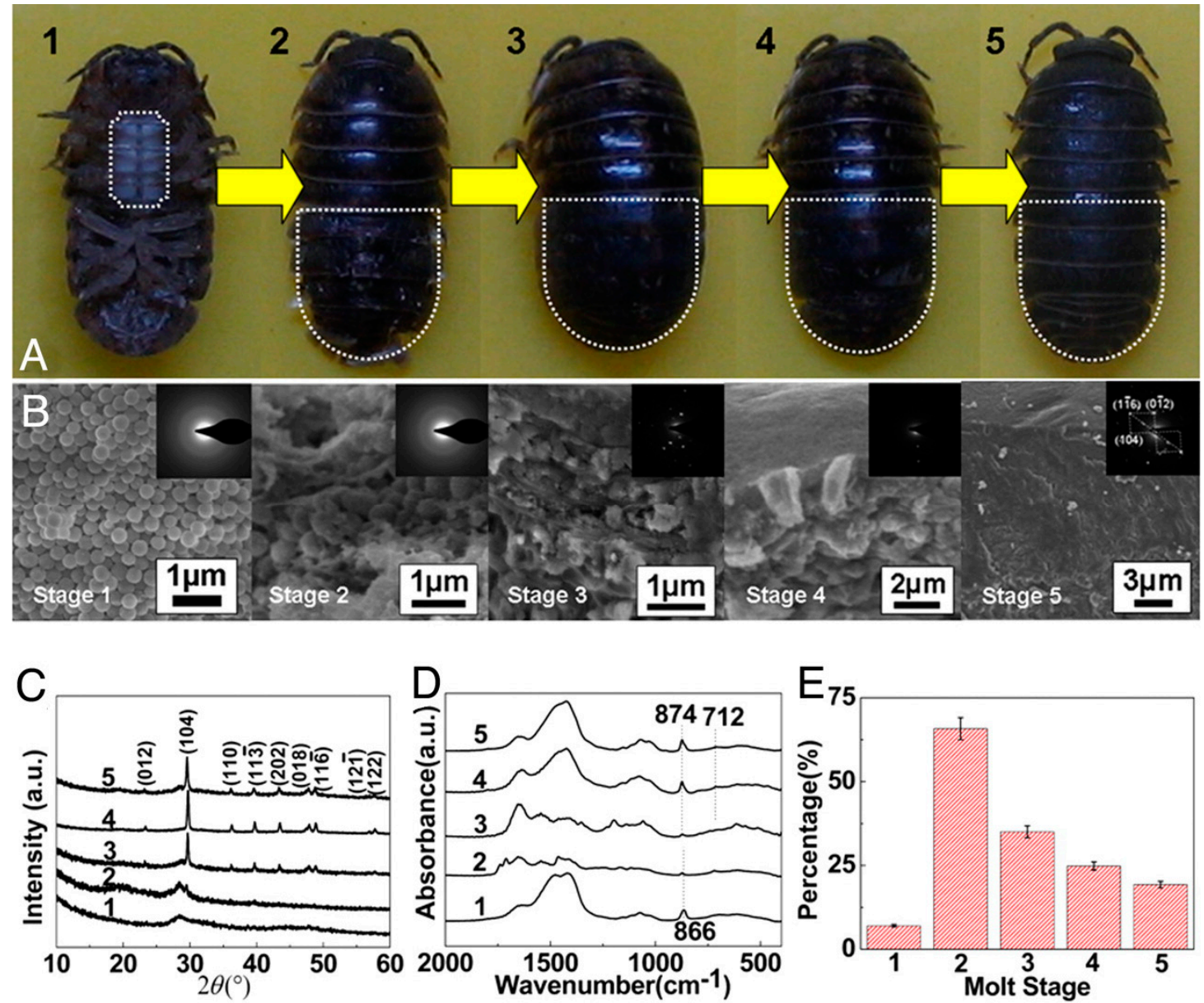

Figure 7. Morphology, phase, and composition of cuticles at different molt stages. The phase transformation process (amorphous calcium carbonate (ACC)-calcite) can be regulated by magnesium and Asp. (A) Photographs of Armadillidium vulgare in the different molt states (1-5). (B) SEM images and SAED patterns of the cross-sections of exocuticle layer shown in (A). (C,D) XRD patterns and Fourier transform infrared (FT-IR) spectra, respectively. (E) Organic contents of the cuticles during the molt process. Reproduced with permission from Reference [155] Copyright (2008) National Academy of Sciences, U.S.A.

\section{Kinetics of Amorphous Mineral Phase-Mediated Crystallization}

The classical crystallization theories (CCTs) have been widely applied towards understanding the crystallization and kinetics of biomimetic mineralization systems. They are especially useful for understanding the promoting or inhibiting effect of NMPs and their analogues on $\mathrm{CaP}$ and $\mathrm{CaC}$ crystallization, the equilibrium morphology of crystals, and the change of step growth rate and step roughness by the control of biomolecules [3,156-165]. However, care should be taken in the direct application of CCT to biomimetic mineralization systems. CCT assumes monomer addition during the crystal nucleation and the crystal growth processes. However, other crystallization pathways might happen in biomimetic mineralization systems [14], such as prenucleation clusters [17-20,166], amorphous phase mediated crystallization, and aggregation-based crystallization [16,145-150]. For these non-classical crystallization pathways, many unexpected crystallization behaviors have been reported, such as faster nucleation of HAP at lower $\mathrm{pH}$ with lower supersaturation [10] and the formation of abnormally high Mg-calcite [132]. For a better understanding of crystallization kinetics among these non-classical crystallization systems, the detailed crystallization pathways have to be taken into account during the deduction of the kinetics models. 


\subsection{Determination of Amorphous Phases and Their Solubility}

Amorphous materials are defined as highly disordered materials [167]. Therefore, it is difficult to reveal the structural information of amorphous materials due to the lack of translational and orientational long-range order (LRO) of the atomic positions. In the past century, the microscopic nature of amorphous materials became possible to understand [167]. ACP is one of the most frequently observed forms in bio- and biomimetic CaP mineralization systems. The first study of ACP structure was done by determining its radial distribution function by Betts and Posner $[168,169]$. In ACP, there exists a short-range order, consistent with $\mathrm{Ca}_{9}\left(\mathrm{PO}_{4}\right)_{6}$ units and an average diameter of $0.95 \mathrm{~nm}$, which are often named "Posner's clusters". Moreover, theoretical investigations show that Posner's clusters are the most stable arrangement compared to different calcium and phosphate clusters $[170,171]$. In comparison with other calcium phosphate phases (for example, dicalcium phosphate dihydrate (DCPD), HAP, tricalcium phosphate (TCP)), ACP is meta-stable and inclined to form a crystalline phase. Therefore, the thermodynamic value of solubility $(-\log (\mathrm{Ks}))$ of ACP cannot be measured strictly. The reported solubility is $25.7 \pm 0.1(\mathrm{pH}=7.4), 29.9 \pm 0.1(\mathrm{pH}=6.00), 32.7 \pm 0.1$ $(\mathrm{pH}=5.28)$ [172]. Furthermore, ACP is thermally unstable after heating, and two types of water loss occur. This corresponds to surface adsorbed water and internal bound water, respectively $[173,174]$. Many techniques were applied to determine the amorphous phase. The XRD pattern of the ACP phase showed only two very broad and diffuse peaks, which is typical for a pattern lacking periodic LRO [175]. FT-IR and Raman methods use several bands in different vibration domains of $\mathrm{PO}_{4}$ groups in the phosphate apatite to distinguish ACP $[47,176]$. Chatzipanagis et al. used in situ time-resolved Raman spectroscopy to monitor amorphous phase structural evolution [176]. Besides XRD, infrared spectroscopy was also used to obtain a quantitative estimate of the amorphous crystallization percentage based on the splitting function [177], which indicated that the crystallinity increases with an increased splitting of the P-O antisymmetric bending mode at $550-600 \mathrm{~cm}^{-1}$. Extended $X$-ray absorption fine structure (EXAFS) spectroscopy was used to investigate the environment of calcium ions in ACP, and Harries et al. pointed out that the data was in agreement with the model proposed by Posner [178]. Moreover, thermal analysis such as differential scanning calorimetry (DSC) is used to determine the amount of the amorphous phase in a mixture based on the exothermic event [179]. Solid-state NMR is a powerful tool for determining the faint changes in ACP, especially ${ }^{1} \mathrm{H}$ spectra which will reveal the presence of small amounts of $\mathrm{HPO}_{4}{ }^{2-}$ and $\mathrm{OH}^{-}$ions undetected by spectroscopic measurements [180].

ACC also shows broad and diffuse peaks in XRD spectrograms at $2 \theta=28^{\circ}$ [181]. EXAFS analysis was used to detect the structural variations of ACC by Taylor et al. [4]. The results showed that there is short-range order around the calcium ions. In the ACC infrared spectrum, the characteristic broad absorption peaks were at $866 \mathrm{~cm}^{-1}\left(v_{2}\right)$ and $1450 \mathrm{~cm}^{-1}\left(v_{3}\right)$, respectively. These peaks are sharpened, split, and shifted when ACC crystallizes [57]. The reported solubility products of ACC are $3.1 \times 10^{-8} \mathrm{M}^{2}$ (ACC I, $\mathrm{pH}=9.00$ to 9.50 ) and $3.8 \times 10^{-8} \mathrm{M}^{2}$ (ACC II, $\mathrm{pH}=9.75$ to 10.0) [17]. However, the exact lower limit of the solubility of ACC is still under debate [182]. Thermogravimetric analysis-mass spectrometry (TGA-MS) and DSC show that an exothermic process occurring at $105^{\circ} \mathrm{C}$ was identified as the transformation of ACC to a crystalline product. A further endothermic process at $149{ }^{\circ} \mathrm{C}$ was discovered to be the loss of water. This was identified by TGA-MS with concurrent formation of calcite. Finally, at around $500{ }^{\circ} \mathrm{C}$, the material decomposed to calcium oxide and carbon dioxide [22].

\subsection{Classical Homogeneous and Heterogeneous Nucleation Theory}

In classical nucleation theory (CNT), with the assumption of the steady state of the chain reactions of monomer additions, the homogeneous nucleation rate, $J_{\mathrm{N}, \text { homo, }}$ can be deduced as $[3,165]$,

$$
J_{\mathrm{N}, \text { homo }}=A \exp \left[\frac{-\Delta G_{\text {homo }}}{k_{B} T}\right]=A \exp \left[\frac{-16 \pi \gamma^{3} \Omega^{2}}{3\left(k_{B} T\right)^{3}(\ln S)^{2}}\right]=A \exp \left[B \frac{\gamma^{3}}{(\ln S)^{2}}\right]
$$


where $A$ is a pre-exponential factor; $\Delta G_{h o m o}$ is the homogenous nucleation barrier; $k_{B}$ is the Boltzmann constant; $T$ is the absolute temperature; $\gamma$ is the interfacial energy between the crystals and the mother phase; $\Omega$ is the volume of the growth units; and $S$ is the supersaturation. In CNT, the nucleation rate has an exponential relationship with and $1 /(\ln S)^{2}$. So, reducing the interfacial energy or increasing the supersaturation would greatly promote the nucleation rate, which has been widely corroborated in many crystallization systems. With respect to biomineralization systems, the biomatrix and NMPs are believed to facilitate crystal nucleation by reducing the interfacial energy of nucleation $[182,183]$ or increasing the local supersaturation by charge attractions [70,184-187].

In a supersaturated solution, when the chain reactions of monomer additions reach the steady state, a spectrum of ionic aggregates is formed with a Boltzmann distribution. The primary species in a solution is still a monomer. A small fraction of ionic aggregates reach a critical size, which is unstable in a supersaturated solution. These ionic aggregates are called the crystal nuclei, and they will grow in a supersaturated solution. As the crystals grow, the supersaturation will gradually decrease and the nucleation rate will decrease as well. So, strictly speaking, the whole crystallization process can be divided into a nucleation-dominated region and a crystal growth-dominate region. At the nucleation-dominated region, a second nucleation will happen on the mother crystal because it has a lower interfacial energy of nucleation (explained below). This event is called self-heterogeneous nucleation. In the other case, if the nucleation event happens on a foreign substrate instead of on the mother crystal (e.g., on the biomatrix), this is called heterogeneous nucleation. For a heterogeneous nucleation, the nucleation rate $\left(J_{\mathrm{N}, \text { hetero }}\right)$ is expressed as $[3,160]$ :

$$
J_{\mathrm{N}, \text { hetero }}=A f_{1} \exp \left[\frac{-\Delta G_{\text {hetero }}}{k_{\mathrm{B}} T}\right]=A f_{1} \exp \left[\frac{-\Delta G_{\text {homo }}}{k_{\mathrm{B}} T} f_{2}\right]
$$

where $f_{1}$ and $f_{2}$ are factors that take into consideration, respectively, the nucleus geometry and the effective interfacial energy of heterogeneous nucleation. Factors $f_{1}$ and $f_{2}$ are less than 1 , so the heterogeneous nucleation is much easier than that of homogeneous nucleation, which can be applied to explain the template effect in biomineralization. This means the biomatrix can reduce the effective interfacial energy of nucleation, especially when the crystallite is nucleated with a specific facet or orientation on the biomatrix. Liu and co-workers further pointed out that the template effect was especially helpful at a moderate or low supersaturated solution [8]. Otherwise, at a much higher supersaturation, the nucleation barrier is too low such that the structure-mismatched nucleation was also ready to happen, which leads to the anti-template effect [8].

\subsection{Amorphous Phase Mediated Nucleation}

The amorphous phase-mediated crystallization pathway complicates the classical understanding of nucleation. For one thing, the formation of amorphous precursors reduces the effective supersaturation of solutions [11]. For another, the amorphous precursors also represent the substrate for the heterogeneous crystal nucleation [10]. A heterogeneous nucleation model was established for an ACP-mediated crystallization system. The nucleation rate of $\mathrm{HAP}, J_{\mathrm{N} \text {,hetero, }}$ can be expressed as $[10,11]$ :

$$
\begin{gathered}
J_{\mathrm{N}, \text { hetero }}=K C\{\mathrm{Ca}\}_{\text {eff }}^{2} \\
K=K_{1} \exp \left(\frac{-\Delta G_{\text {react }}^{*}}{k_{\mathrm{B}} T}\right) \exp \left(\frac{-\Delta G_{\mathrm{N}, \text { hetero }}^{*}}{k_{\mathrm{B}} T}\right) f
\end{gathered}
$$

where $\Delta G^{*}$ react is the chemical reaction barrier for the incorporation of free calcium ions into HAP nuclei; $\Delta G^{*}$,hetero is the nucleation barrier for the heterogeneous nucleation of HAP from ACP; $f$ is the converting factor from surface area $(A)$ to the amount of amorphous phase $(C)$ (i.e., $\mathrm{A}=f \mathrm{C}$ ); $\{\mathrm{Ca}\}_{\mathrm{eff}}$ is the effective activity of calcium ions (after the precipitation of $\mathrm{ACP}$ ); $K_{1}$ is the pre-exponential factor; and $k_{\mathrm{B}}$ is the Boltzmann constant. 
This model is also different from classical heterogeneous nucleation. First, the substrate (amorphous precursors) is involved in the reaction of nucleation:

$$
3 \mathrm{Ca}_{3}\left(\mathrm{PO}_{4}\right)_{2}(\mathrm{~s})+\mathrm{Ca}^{2+}+2 \mathrm{H}_{2} \mathrm{O} \rightarrow 2 \mathrm{Ca}_{5}\left(\mathrm{PO}_{4}\right)_{3}(\mathrm{OH})(\mathrm{s})+2 \mathrm{H}^{+}
$$

After the reaction, the substrate material is converted into the crystal phase. Second, calcium ions from solution are needed to keep the stoichiometry of HAP (see Equation (5)). Lastly, for a given system, the effective supersaturation can be taken as a constant regardless of how much calcium and phosphate ions were initially put into solution. This is because the excess amount of calcium and phosphate ions will precipitate as ACP precursors and the solution will become saturated with respect to $\mathrm{ACP}$. In such a crystallization model, the nucleation rate is only dependent upon the amount of precipitated ACP and the effective activity of calcium ions in the solution [10,11]. This model is helpful for understanding the nucleation kinetics of ACP-mediated crystallizations. We have found an unexpectedly faster nucleation of HAP in SBF solutions with lower $\mathrm{pH}$ [10], which has lower supersaturation. This abnormal crystallization behavior is not understood by CNT, but can be explained by our model. To our understanding, the lower $\mathrm{pH}$ decreases the activity of $\left\{\mathrm{PO}_{4}{ }^{3-}\right\}$. To keep the ionic product of ACP, $\left\{\mathrm{Ca}^{2+}\right\}$ needs to be increased, which can promote the ACP-mediated crystallization (Figure 8). This model can also be applied to explain the stability change of ACP by its aggregation state [86] and its size [85].
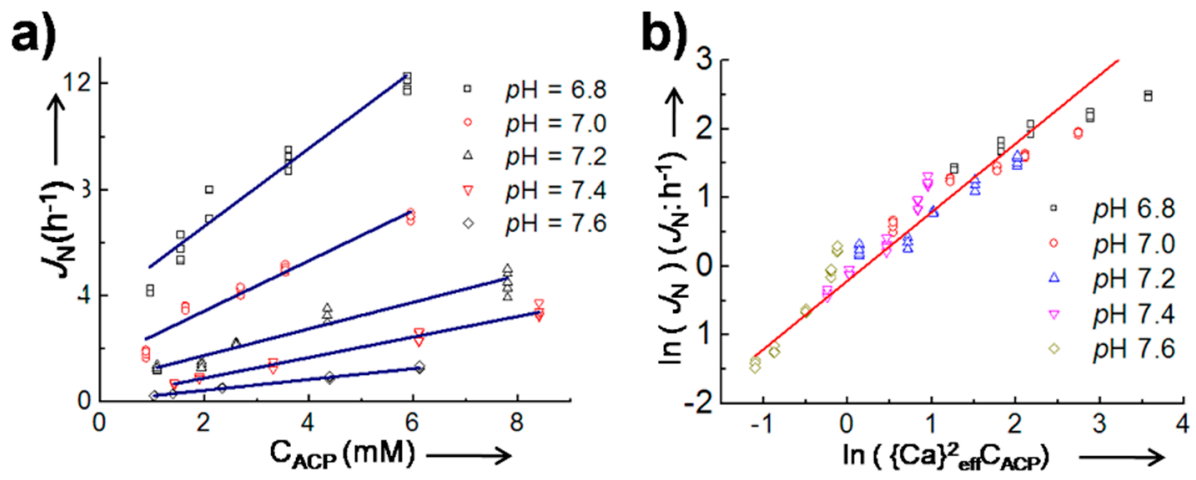

Figure 8. Nucleation rate, $J_{\mathrm{N}}$, was related to (a) the amount of precipitated amorphous calcium phosphate $(\mathrm{ACP})\left(\mathrm{C}_{\mathrm{ACP}}, \mathrm{mM}\right)$ and $(\mathbf{b})$ effective calcium activity $\left(\left\{\mathrm{Ca}^{2+}\right\}, \mathrm{mM}\right)$. Reproduced with permission from the Royal Society of Chemistry in Reference [10].

It should be noted that our model is applicable when a crystal phase is nucleated directly from an amorphous phase. However, different crystal nucleation pathways might happen for amorphous precursor phases such as the dissolution/reprecipitation-based pathway (crystal nucleation from solutions) [49-56] and the direct amorphous-crystallite solid-solid structure reorganization pathway (nucleation from amorphous phases) [19,33,57-61]. For the dissolution/reprecipitation-based pathway, the classical homogeneous nucleation model is a good starting point for deducing the kinetics model. However, care should be taken when determining the effective supersaturation and the effective volume of the nucleation systems (the nucleation rate is inversely proportional to the volume of the mother phase). De Yoreo and co-workers have reported one crystallization pathway of the dissolution and reprecipitation of ACC-mediated crystallization [182]. For the crystallization of calcite on an $\mathrm{OH}$-terminated SAM (mercapto-undecanol, MUO) film, the nucleation rate showed no dependence on the initial solution supersaturation. This phenomenon was explained by the effective supersaturation: once ACC formed homogenously, the solute concentration immediately became fixed at the solubility of ACC, regardless of the initial solution conditions.

The solid-solid phase transformation of amorphous precursor systems is frequently observed for air-dried ACC particles at high temperature $\left(\sim 300{ }^{\circ} \mathrm{C}\right)$ (Figure 9) [57]. Air-/freeze-dried or 
ethanol dehydrated ACC in dried air condition is much more stable than that in solution or in humid conditions $[188,189]$, which indicates that the direct solid-solid phase transformation barrier is higher than the solution-based nucleation barrier. The solid-solid transformation is not a single step. Different stages of the water dehydration of ACC were observed before the crystallization [57]. Quantitative thermal analysis and ssNMR studies demonstrated that ACC undergoes parallel dehydration and structural changes before a subsequent "solid-state" transformation. The loss of the final portion of water (15 wt \% of the initial water content) triggers crystallization. However, this step is associated with a high free energy barrier $\left(\sim 245 \mathrm{~kJ} \cdot \mathrm{mol}^{-1}\right)$ such that at room temperature the first crystal nucleus can only form via a dissolution/reprecipitation mechanism mediated by water present on particle surfaces or in solution. The confinement probably creates a barrier to water diffusion [53], which slows the dissolution/reprecipitation-based nucleation pathway and stabilizes ACC. This suggests that nature employs nano-confinement to tailor the stability of ACC in organisms.

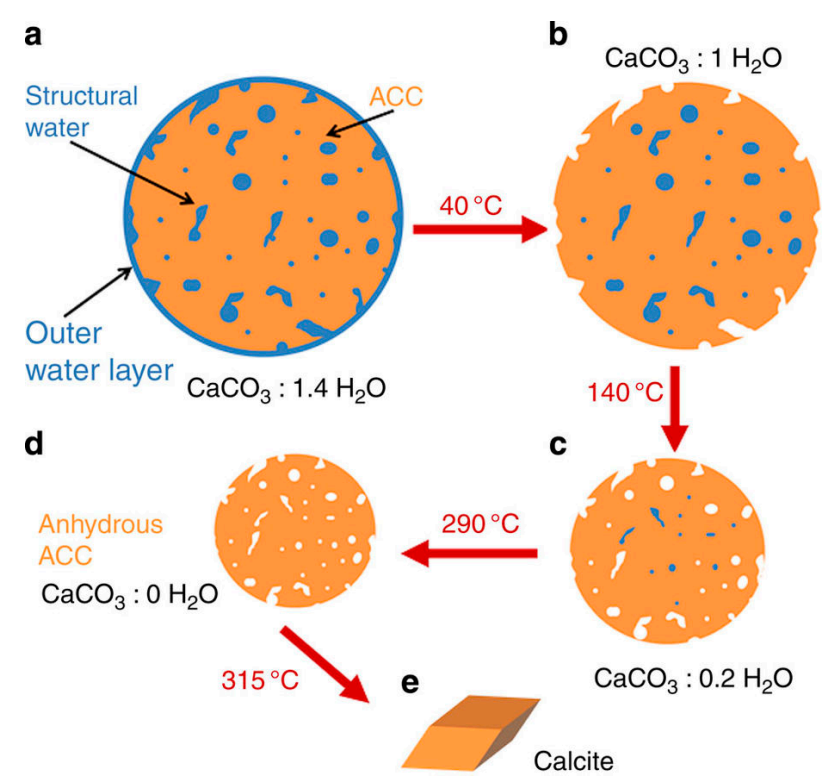

Figure 9. Schematic of stages of ACC dehydration. The solid-solid transformation is followed by water dehydration of ACC. Upon going from $\mathbf{a}$ to $\mathbf{b}$, surface-bound water is lost, during $\mathbf{b}$ to $\mathbf{c}$ water is lost from the interior of the ACC and the ACC particle shrinks. Going from $\mathbf{c}$ to $\mathbf{d}$, the most deeply located water is expelled, and from $\mathbf{d}$ to $\mathbf{e}$, crystallization to calcite occurs. Reproduced with permission from Macmillan Publishers Limited in Reference [57].

\section{Conclusions}

APMC pathways have been widely observed in a variety of biomineralization systems, and have been reproduced in the biomimetic mineralization in supersaturated solutions, in assembled organic matrix or nano-compartment, and in the presence of NMPs, which mimic the micro-environments of biomineralization. Bio-mimicking experiments applying the amorphous mediated crystallization pathways have shown advantages for developing hierarchically structured morphology, bone-apatite coating, oriented crystallization in confined spaces, and retro- or morpho-synthesis of mollusk-shell like structures. These investigations will surely enhance our understanding of biomineralization mechanisms.

The pathways and mechanisms of amorphous phase mediated crystallization are fundamental to biomineralization systems. Although extensive investigations of calcium phosphate and calcium carbonate crystallization have been performed, many of them focus on mimicking the morphology and superstructure of biominerals. The detailed crystallization pathways and the quantitative measurements of the kinetics of amorphous-based crystallization systems remain largely unexplored, 
and further resources need to be employed in this area. Some detailed issues, such as the fluidic or surface properties of the amorphous precursor phases (e.g., PILP or prenucleation precursors), how precursor phase gets into the nano-compartment (i.e., could it be limited by diffusion or in situ induced?) of biomatrix, and the interaction sites of NMPs on amorphous phase or biomatrix, still remain largely unknown, but are key for understanding the details of biomineralization processes. In situ measurements are significant for revealing the details of the amorphous transformation process. These measurements include in situ $\mathrm{pH}$ or ionic monitoring, atomic force microscopy (AFM), electron microscopy, X-ray spectroscopy, thermal analysis, and ssNMR [190].

The previously corroborated classical nucleation and crystal growth theories have been found to be inappropriate for APMC systems. As such, the deduction of kinetics models for APMC systems is urgent due to the correlation with biomineralization systems. Some "abnormal" crystallization behavior in biomineralization-such as abnormally high $\mathrm{Mg}$ content in minerals, abnormal stability of precursor phases, abnormally precise control of crystal phases and orientations, abnormal reproducibility, abnormally uniform size and spatial distributions of minerals, and the vital effects $[39,191]$ - would benefit from these theoretical advances. The fundamental and quantitative investigation of a small well-defined system would have a large impact on the understanding of biomineralization mechanisms, which would inspire the development of many functional materials with unlimited patterns and morphologies to solve global problems regarding the environment [192-194], energy [195-198], and healthcare [199-202].

Acknowledgments: This research was supported by the National Natural Science Foundation of China (21625105 and 21771160), the Zhejiang Provincial Natural Science Foundation of China (LY17B010001), and the Fundamental Research Funds for Central Universities (2016QN81020).

Author Contributions: All authors contributed equally to this manuscript.

Conflicts of Interest: The authors declare no conflict of interest.

\section{References}

1. Mann, S. General principles of biomineralization. In Biominer. Princ. Concepts Bioinorg. Mater. Chem; Oxford University Press: New York, NY, USA, 2002.

2. Lowenstam, H.A.; Weiner, S. On Biomineralization; Oxford University Press: New York, NY, USA, 1989.

3. De Yoreo, J.; Vekilov, P.G. Principles of Crystal Nucleation and Growth. Rev. Miner. Geochem. 2003, 54, 57-93. [CrossRef]

4. Taylor, M.G.; Simkiss, K.; Greaves, G.N.; Okazaki, M.; Mann, S. An X-ray absorption spectroscopy study of the structure and transformation of amorphous calcium carbonate from plant cystoliths. Proc. R. Soc. Lond. Ser. B-Biol. Sci. 1993, 252, 75-80. [CrossRef]

5. Bauer, P.; Elbaum, R.; Weiss, I.M. Calcium and silicon mineralization in land plants: Transport, structure and function. Plant. Sci. 2011, 180, 746-756. [CrossRef] [PubMed]

6. Gal, A.; Hirsch, A.; Siegel, S.; Li, C.; Aichmayer, B.; Politi, Y.; Fratzl, P.; Weiner, S.; Addadi, L. Plant cystoliths: A complex functional biocomposite of four distinct silica and amorphous calcium carbonate phases. Chem.-A Eur. J. 2012, 18, 10262-10270. [CrossRef] [PubMed]

7. He, H.; Veneklaas, E.J.; Kuo, J.; Lambers, H. Physiological and ecological significance of biomineralization in plants. Trends Plant. Sci. 2014, 19, 166-174. [CrossRef] [PubMed]

8. Liu, X.Y.; Lim, S.W. Templating and supersaturation-driven anti-templating: Principles of biomineral architecture. J. Am. Chem. Soc. 2003, 125, 888-895. [CrossRef] [PubMed]

9. Wang, L.; Nancollas, G.H. Calcium orthophosphates: Crystallization and dissolution. Chem. Rev. 2008, 108, 4628-4669. [CrossRef] [PubMed]

10. Jiang, S.; Chen, Y.; Pan, H.; Zhang, Y.-J.; Tang, R. Faster nucleation at lower pH: Amorphous phase mediated nucleation kinetics. Phys. Chem. Chem. Phys. 2013, 15, 12530. [CrossRef] [PubMed]

11. Jiang, S.; Pan, H.; Chen, Y.; Xu, X.; Tang, R. Amorphous calcium phosphate phase-mediated crystal nucleation kinetics and pathway. Faraday Discuss. 2015, 179, 451-461. [CrossRef] [PubMed] 
12. Blue, C.R.; Giuffre, A.; Mergelsberg, S.; Han, N.; De Yoreo, J.J.; Dove, P.M. Chemical and physical controls on the transformation of amorphous calcium carbonate into crystalline $\mathrm{CaCO}_{3}$ polymorphs. Geochim. Cosmochim. Acta 2017, 196, 179-196. [CrossRef]

13. Liu, X.Y.; De Yoreo, J. Nanoscale Structure and Assembly at Solid-Fluid Interfaces: Assembly in Hybrid and Biological Systems; Kluwer Academic Press: Dordrecht, The Netherlands, 2004.

14. De Yoreo, J.J.; Gilbert, P.U.P.A.; Sommerdijk, N.A.J.M.; Penn, R.L.; Whitelam, S.; Joester, D.; Zhang, H.; Rimer, J.D.; Navrotsky, A.; Banfield, J.F.; et al. Crystallization by particle attachment in synthetic, biogenic, and geologic environments. Science 2015, 349, aaa6760. [CrossRef] [PubMed]

15. Banfield, J.F. Aggregation-Based Crystal growth and microstructure development in natural iron oxyhydroxide biomineralization products. Science 2000, 289, 751-754. [CrossRef] [PubMed]

16. Cölfen, H.; Mann, S. Higher-order organization by mesoscale self-assembly and transformation of hybrid nanostructures. Angew. Chem.-Int. Ed. 2003, 42, 2350-2365. [CrossRef] [PubMed]

17. Gebauer, D.; Volkel, A.; Colfen, H. Stable prenucleation calcium carbonate clusters. Science 2008, 322, 1819-1822. [CrossRef] [PubMed]

18. Gebauer, D.; Cölfen, H. Prenucleation clusters and non-classical nucleation. Nano Today 2011, 6, 564-584. [CrossRef]

19. Pouget, E.M.; Bomans, P.H.H.; Goos, J.A.C.M.; Frederik, P.M.; de With, G.; Sommerdijk, N.A.J.M. The initial stages of template-controlled $\mathrm{CaCO}_{3}$ formation revealed by cryo-TEM. Science 2009, 323, 1455-1458. [CrossRef] [PubMed]

20. Dey, A.; Bomans, P.H.H.; Müller, F.A.; Will, J.; Frederik, P.M.; de With, G.; Sommerdijk, N.A.J.M. The role of prenucleation clusters in surface-induced calcium phosphate crystallization. Nat. Mater. 2010, 9, 1010-1014. [CrossRef] [PubMed]

21. Gower, L.B. Biomimetic model systems for investigating the amorphous precursor pathway and its role in biomineralization. Chem. Rev. 2008, 108, 4551-4627. [CrossRef] [PubMed]

22. Faatz, M.; Gröhn, F.; Wegner, G. Amorphous calcium carbonate: Synthesis and potential intermediate in biomineralization. Adv. Mater. 2004, 16, 996-1000. [CrossRef]

23. Addadi, L.; Raz, S.; Weiner, S. Taking advantage of disorder: Amorphous calcium carbonate and its roles in biomineralization. Adv. Mater. 2003, 15, 959-970. [CrossRef]

24. Dorozhkin, S.V. Amorphous calcium (ortho)phosphates. Acta Biomater. 2010, 6, 4457-4475. [CrossRef] [PubMed]

25. Weiner, S.; Mahamid, J.; Politi, Y.; Ma, Y.; Addadi, L. Overview of the amorphous precursor phase strategy in biomineralization. Front. Mater. Sci. China 2009, 3, 104-108. [CrossRef]

26. Cartwright, J.H.E.; Checa, A.G.; Gale, J.D.; Gebauer, D.; Sainz-Díaz, C.I. Calcium carbonate polyamorphism and its role in biomineralization: How many amorphous calcium carbonates are there? Angew. Chem.-Int. Ed. 2012, 51, 11960-11970. [CrossRef] [PubMed]

27. Termine, J.D.; Posner, A.S. Infrared analysis of rat bone: Age dependency of amorphous and crystalline mineral fractions. Science 1966, 153, 1523-1525. [CrossRef] [PubMed]

28. Boskey, A.L. Amorphous calcium phosphate: The contention of bone. J. Dent. Res. 1997, 76, 1433-1436. [CrossRef] [PubMed]

29. Mahamid, J.; Aichmayer, B.; Shimoni, E.; Ziblat, R.; Li, C.; Siegel, S.; Paris, O.; Fratzl, P.; Weiner, S.; Addadi, L. Mapping amorphous calcium phosphate transformation into crystalline mineral from the cell to the bone in zebrafish fin rays. Proc. Natl. Acad. Sci. USA 2010, 107, 6316-6321. [CrossRef] [PubMed]

30. Nudelman, F.; Bomans, P.H.H.; George, A.; de With, G.; Sommerdijk, N.A.J.M. The role of the amorphous phase on the biomimetic mineralization of collagen. Faraday Discuss. 2012, 159, 357. [CrossRef] [PubMed]

31. Olszta, M.J.; Cheng, X.; Jee, S.S.; Kumar, R.; Kim, Y.Y.; Kaufman, M.J.; Douglas, E.P.; Gower, L.B. Bone structure and formation: A new perspective. Mater. Sci. Eng. R Rep. 2007, 58, 77-116. [CrossRef]

32. Sailaja, G.S.; Ramesh, P.; Varma, H.K. Ultrastructural evaluation of in vitro mineralized calcium phosphate phase on surface phosphorylated poly(hydroxy ethyl methacrylate-co-methyl methacrylate). J. Mater. Sci. Mater. Med. 2010, 21, 1183-1193. [CrossRef] [PubMed]

33. Onuma, K. Recent research on pseudobiological hydroxyapatite crystal growth and phase transition mechanisms. Prog. Cryst. Growth Charact. Mater. 2006, 52, 223-245. [CrossRef] 
34. Barrere, F.; Snel, M.M.E.; Van Blitterswijk, C.A.; De Groot, K.; Layrolle, P. Nano-scale study of the nucleation and growth of calcium phosphate coating on titanium implants. Biomaterials 2004, 25, 2901-2910. [CrossRef] [PubMed]

35. Politi, Y.; Metzler, R.A.; Abrecht, M.; Gilbert, B.; Wilt, F.H.; Sagi, I.; Addadi, L.; Weiner, S.; Gilbert, P.U.P.A. Transformation mechanism of amorphous calcium carbonate into calcite in the sea urchin larval spicule. Proc. Natl. Acad. Sci. USA 2008, 105, 17362-17366. [CrossRef] [PubMed]

36. Politi, Y. Sea Urchin spine calcite forms via a transient amorphous calcium carbonate phase. Science 2004, 306, 1161-1164. [CrossRef] [PubMed]

37. Addadi, L.; Joester, D.; Nudelman, F.; Weiner, S. Mollusk shell formation: A source of new concepts for understanding biomineralization processes. Chem.-A Eur. J. 2006, 12, 980-987. [CrossRef] [PubMed]

38. Nassif, N.; Pinna, N.; Gehrke, N.; Antonietti, M.; Jager, C.; Colfen, H. Amorphous layer around aragonite platelets in nacre. Proc. Natl. Acad. Sci. USA 2005, 102, 12653-12655. [CrossRef] [PubMed]

39. Weiner, S. An Overview of biomineralization processes and the problem of the vital effect. Rev. Miner. Geochem. 2003, 54, 1-29. [CrossRef]

40. Mass, T.; Giuffre, A.J.; Sun, C.-Y.; Stifler, C.A.; Frazier, M.J.; Neder, M.; Tamura, N.; Stan, C.V.; Marcus, M.A.; Gilbert, P.U.P.A. Amorphous calcium carbonate particles form coral skeletons. Proc. Natl. Acad. Sci. USA 2017, 114, 7670-7678. [CrossRef] [PubMed]

41. Combes, C.; Rey, C. Amorphous calcium phosphates: Synthesis, properties and uses in biomaterials. Acta Biomater. 2010, 6, 3362-3378. [CrossRef] [PubMed]

42. Xu, X.R.; Cai, A.H.; Liu, R.; Pan, H.H.; Tang, R.K.; Cho, K. The roles of water and polyelectrolytes in the phase transformation of amorphous calcium carbonate. J. Cryst. Growth 2008, 310, 3779-3787. [CrossRef]

43. Gal, A.; Habraken, W.; Gur, D.; Fratzl, P.; Weiner, S.; Addadi, L. Calcite crystal growth by a solid-state transformation of stabilized amorphous calcium carbonate nanospheres in a hydrogel. Angew. Chem.—Int. Ed. 2013, 52, 4867-4870. [CrossRef] [PubMed]

44. Tester, C.C.; Wu, C.H.; Krejci, M.R.; Mueller, L.; Park, A.; Lai, B.; Chen, S.; Sun, C.; Balasubramanian, M.; Joester, D. Time-resolved evolution of short- and long-range order during the transformation of amorphous calcium carbonate to calcite in the sea urchin embryo. Adv. Funct. Mater. 2013, 23, 4185-4194. [CrossRef]

45. Nielsen, M.H.; Aloni, S.; De Yoreo, J.J. In situ TEM imaging of $\mathrm{CaCO}_{3}$ nucleation reveals coexistence of direct and indirect pathways. Science 2014, 345, 1158-1162. [CrossRef] [PubMed]

46. Puech, J.; Heughebaert, J.-C.; Montel, G. A new mode of growing apatite crystallites. J. Cryst. Growth 1982, 56, 20-25. [CrossRef]

47. Chatzipanagis, K.; Iafisco, M.; Roncal-Herrero, T.; Bilton, M.; Tampieri, A.; Kröger, R.; Delgado-López, J.M. Crystallization of citrate-stabilized amorphous calcium phosphate to nanocrystalline apatite: A surface-mediated transformation. CrystEngComm 2016, 18, 3170-3173. [CrossRef]

48. Pan, H.; Liu, X.Y.; Tang, R.; Xu, H.Y. Mystery of the transformation from amorphous calcium phosphate to hydroxyapatite. Chem. Commun. 2010, 46, 7415-7417. [CrossRef] [PubMed]

49. Posner, A.; Betts, F. Synthetic amorphous calcium-phosphate and its relation to bone-mineral structure. Acc. Chem. Res. 1975, 8, 273-281. [CrossRef]

50. Lazić, S. Microcrystalline hydroxyapatite formation from alkaline solutions. J. Cryst. Growth 1995, 147, 147-154. [CrossRef]

51. Boskey, A.; Posner, A. Conversion of amorphous calcium phosphate to microcrystalline hydroxyapatite. A pH-dependent, solution-mediated, solid-solid conversion. J. Phys. Chem. 1973, 77, 2313-2317. [CrossRef]

52. Somrani, S.; Banu, M.; Jemal, M.; Rey, C. Physico-chemical and thermochemical studies of the hydrolytic conversion of amorphous tricalcium phosphate into apatite. J. Solid State Chem. 2005, 178, 1337-1348. [CrossRef]

53. Tung, M.S.; Brown, W.E. An intermediate state in hydrolysis of amorphous calcium phosphate. Calcif. Tissue Int. 1983, 35, 783-790. [CrossRef] [PubMed]

54. Rodriguez-Blanco, J.D.; Shaw, S.; Bots, P.; Roncal-Herrero, T.; Benning, L.G. The role of $\mathrm{pH}$ and $\mathrm{Mg}$ on the stability and crystallization of amorphous calcium carbonate. J. Alloys Compd. 2012, 536, 477-479. [CrossRef]

55. Kwon, K.Y.; Wang, E.; Nofal, M.; Lee, S.W. Microscopic study of hydroxyapatite dissolution as affected by fluoride ions. Langmuir 2011, 27, 5335-5339. [CrossRef] [PubMed] 
56. Lee, J.R.I.; Han, T.Y.J.; Willey, T.M.; Wang, D.; Meulenberg, R.W.; Nilsson, J.; Dove, P.M.; Terminello, L.J.; Van Buuren, T.; De Yoreo, J.J. Structural development of mercaptophenol self-assembled monolayers and the overlying mineral phase during templated $\mathrm{CaCO}_{3}$ crystallization from a transient amorphous film. J. Am. Chem. Soc. 2007, 129, 10370-10381. [CrossRef] [PubMed]

57. Ihli, J.; Wong, W.C.; Noel, E.H.; Kim, Y.-Y.; Kulak, A.N.; Christenson, H.K.; Duer, M.J.; Meldrum, F.C. Dehydration and crystallization of amorphous calcium carbonate in solution and in air. Nat. Commun. 2014, 5, 1-10. [CrossRef] [PubMed]

58. Wang, C.; Liao, J.; Gou, B.; Huang, J.; Tang, R.; Tao, J.; Zhang, T.; Wang, K. Crystallization at Multiple Sites inside Particles of Amorphous Calcium Phosphate. Cryst. Growth Des. 2009, 9, 2620-2626. [CrossRef]

59. Kim, S.; Ryu, H.S.; Shin, H.; Jung, H.S.; Hong, K.S. In situ observation of hydroxyapatite nanocrystal formation from amorphous calcium phosphate in calcium-rich solutions. Mater. Chem. Phys. 2005, 91, 500-506. [CrossRef]

60. Abbona, F.; Baronnet, A. A XRD and TEM study on the transformation of amorphous calcium phosphate in the presence of magnesium. J. Cryst. Growth 1996, 165, 98-105. [CrossRef]

61. Onuma, K.; Ito, A. Cluster growth model for hydroxyapatite. Chem. Mater. 1998, 10, 3346-3351. [CrossRef]

62. Amos, F.F.; Sharbaugh, D.M.; Talham, D.R.; Gower, L.B.; Fricke, M.; Volkmer, D. Formation of single-crystalline aragonite tablets/films via an amorphous precursor. Langmuir 2007, 23, 1988-1994. [CrossRef] [PubMed]

63. Weiner, S.; Lowenstam, H. Organization of Extracellularly Mineralized Tissues: A Comparative Study of Biological Crystal Growt. Crit. Rev. Biochem. 1986, 20, 365-408. [CrossRef]

64. Mahamid, J.; Sharir, A.; Addadi, L.; Weiner, S. Amorphous calcium phosphate is a major component of the forming fin bones of zebrafish: Indications for an amorphous precursor phase. Proc. Natl. Acad. Sci. USA 2008, 105, 12748-12753. [CrossRef] [PubMed]

65. Boonrungsiman, S.; Gentleman, E.; Carzaniga, R.; Evans, N.D.; McComb, D.W.; Porter, A.E.; Stevens, M.M. The role of intracellular calcium phosphate in osteoblast-mediated bone apatite formation. Proc. Natl. Acad. Sci. USA 2012, 109, 14170-14175. [CrossRef] [PubMed]

66. Beniash, E.; Metzler, R.A.; Lam, R.S.K.; Gilbert, P.U.P.A. Transient amorphous calcium phosphate in forming enamel. J. Struct. Biol. 2009, 166, 133-143. [CrossRef] [PubMed]

67. Lowenstam, H.A.; Weiner, S. Transformation of amorphous calcium phosphate to crystalline dahllite in the radular teeth of chitons. Science 1985, 227, 51-54. [CrossRef] [PubMed]

68. Lévêque, I.; Cusack, M.; Davis, S.A.; Mann, S. Promotion of fluorapatite crystallization by soluble-matrix proteins from Lingula anatina shells. Angew. Chem. Int. Ed. 2004, 43, 885-888. [CrossRef] [PubMed]

69. Fricke, M.; Volkmer, D. Crystallization of calcium carbonate beneath insoluble monolayers: Suitable models of mineral-matrix interactions in biomineralization? Top. Curr. Chem. 2006, 270, 1-41.

70. Weiner, S.; Addadi, L. Design strategies in mineralized biological materials. J. Mater. Chem. 1997, 7, 689-702. [CrossRef]

71. Weiss, I.M.; Tuross, N.; Addadi, L.; Weiner, S. Mollusc larval shell formation: Amorphous calcium carbonate is a precursor phase for aragonite. J. Exp. Zool. Part. A Ecol. Genet. Physiol. 2002, 293, 478-491. [CrossRef] [PubMed]

72. Oyane, A.; Kim, H.-M.; Furuya, T.; Kokubo, T.; Miyazaki, T.; Nakamura, T. Preparation and assessment of revised simulated body fluids. J. Biomed. Mater. Res. 2003, 65, 188-195. [CrossRef] [PubMed]

73. Kokubo, T.; Takadama, H. How useful is SBF in predicting in vivo bone bioactivity? Biomaterials 2006, 27, 2907-2915. [CrossRef] [PubMed]

74. Kokubo, T.; Kushitani, H.; Ebisawa, Y.; Kitsugi, T.; Kotani, S.; Oura, K.; Yamamuro, T. Apatite formation on bioactive ceramics in body environment. Bioceramics 1989, 1, 157-162.

75. Lu, X.; Leng, Y. Theoretical analysis of calcium phosphate precipitation in simulated body fluid. Biomaterials 2005, 26, 1097-1108. [CrossRef] [PubMed]

76. Oyane, A.; Onuma, K.; Kokubo, T.; Ito, A. Clustering of Calcium Phosphate in the System $\mathrm{CaCl}_{2}-\mathrm{H}_{3} \mathrm{PO}_{4}-\mathrm{KCl}-\mathrm{H}_{2} \mathrm{O}$. J. Phys. Chem. B 1999, 103, 8230-8235. [CrossRef]

77. Kim, H.-M.; Himeno, T.; Kawashita, M.; Kokubo, T.; Nakamura, T. The mechanism of biomineralization of bone-like apatite on synthetic hydroxyapatite: An in vitro assessment. J. R. Soc. Interface 2004, 1, 17-22. [CrossRef] [PubMed] 
78. Rhee, S.H.; Tanaka, J. Effect of citric acid on the nucleation of hydroxyapatite in a simulated body fluid. Biomaterials 1999, 20, 2155-2160. [CrossRef]

79. Bleek, K.; Taubert, A. New developments in polymer-controlled, bioinspired calcium phosphate mineralization from aqueous solution. Acta Biomater. 2013, 9, 6283-6321. [CrossRef] [PubMed]

80. Müller, L.; Müller, F.A. Preparation of SBF with different $\mathrm{HCO}_{3}{ }^{-}$content and its influence on the composition of biomimetic apatites. Acta Biomater. 2006, 2, 181-189. [CrossRef] [PubMed]

81. Lee, J.T.Y.; Leng, Y.; Chow, K.L.; Ren, F.; Ge, X.; Wang, K.; Lu, X. Cell culture medium as an alternative to conventional simulated body fluid. Acta Biomater. 2011, 7, 2615-2622. [CrossRef] [PubMed]

82. Tao, J.; Pan, H.; Wang, J.; Wu, J.; Wang, B.; Xu, X.; Tang, R. Evolution of amorphous calcium phosphate to hydroxyapatite probed by gold nanoparticles. J. Phys. Chem. C 2008, 112, 14929-14933. [CrossRef]

83. Blumenthal, N.C.; Posner, A.S. Hydroxyapatite: Mechanism of formation and properties. Calcif. Tissue Int. 1973, 13, 235-243. [CrossRef]

84. Chen, Y.; Gu, W.; Pan, H.; Jiang, S.; Tang, R. Stabilizing amorphous calcium phosphate phase by citrate adsorption. CrystEngComm 2014, 16, 1864-1867. [CrossRef]

85. Wang, Y.-N.; Jiang, S.; Pan, H.; Tang, R. Less is more: Silicate in the crystallization of hydroxyapatite in simulated body fluids. CrystEngComm 2016, 18, 379-383. [CrossRef]

86. Jiang, S.; Jin, W.; Wang, Y.-N.; Pan, H.; Sun, Z.; Tang, R. Effect of the aggregation state of amorphous calcium phosphate on hydroxyapatite nucleation kinetics. RSC Adv. 2017, 7, 25497-25503. [CrossRef]

87. Kim, S.; Ryu, H.S.; Shin, H.; Jung, H.S.; Hong, K.S. Direct observation of hydroxyapatite nucleation from amorphous phase in a stoichiometric calcium/phosphate aqueous solution. Chem. Lett. 2004, 33, 1292-1293. [CrossRef]

88. Gattuso, J.-P.; Frankignoulle, M.; Bourge, I.; Romaine, S.; Buddemeier, R.W. Effect of calcium carbonate saturation of seawater on coral calcification. Glob. Planet. Chang. 1998, 18, 37-46. [CrossRef]

89. Stanley, S.M. Effects of global seawater chemistry on biomineralization: Past, present, and future. Chem. Rev. 2008, 108, 4483-4498. [CrossRef] [PubMed]

90. Ries, J.B.; Stanley, S.M.; Hardie, L.A. Scleractinian corals produce calcite, and grow more slowly, in artificial Cretaceous seawater. Geology 2006, 34, 525-528. [CrossRef]

91. Reddy, M.M.; Nancollas, G.H. The crystallization of calcium carbonate: IV. The effect of magnesium, strontium and sulfate ions. J. Cryst. Growth 1976, 35, 33-38. [CrossRef]

92. Berner, R.A. The role of magnesium in the crystal growth of calcite and aragonite from sea water. Geochim. Cosmochim. Acta 1975, 39, 489IN3495-494504. [CrossRef]

93. Mucci, A.; Morse, J.W. The incorporation of $\mathrm{Mg}^{2+}$ and $\mathrm{Sr}^{2+}$ into calcite overgrowths: Influences of growth rate and solution composition. Geochim. Cosmochim. Acta 1983, 47, 217-233. [CrossRef]

94. Stanley, S.M. Influence of seawater chemistry on biomineralization throughout Phanerozoic time: Paleontological and experimental evidence. Palaeogeogr. Palaeoclimatol. Palaeoecol. 2006, 232, 214-236. [CrossRef]

95. Purgstaller, B.; Konrad, F.; Dietzel, M.; Immenhauser, A.; Mavromatis, V. Control of $\mathrm{Mg}^{2+} / \mathrm{Ca}^{2+}$ activity ratio on the formation of crystalline carbonate minerals via an amorphous precursor. Cryst. Growth Des. 2017, 17, 1069-1078. [CrossRef]

96. Shen, X.; Belcher, A.M.; Hansma, P.K.; Stucky, G.D.; Morse, D.E. Molecular cloning and characterization of lustrin A, a matrix protein from shell and pearl nacre of Haliotis rufescens. J. Biol. Chem. 1997, 272, 32472-32481. [CrossRef] [PubMed]

97. Pereira-Mouriès, L.; Almeida, M.; Ribeiro, C.; Peduzzi, J.; Barthélemy, M.; Milet, C.; Lopez, E. Soluble silk-like organic matrix in the nacreous layer of the bivalve Pinctada maxima. FEBS J. 2002, 269, 4994-5003. [CrossRef]

98. Time-Lapse, S.C.S.; Franz, C.M.; Muller, D.J. Atomic force microscopy in biomedical research. Methods 2011, 736, 97-107.

99. Orgel, J.P.R.O.; Irving, T.C.; Miller, A.; Wess, T.J. Microfibrillar structure of type I collagen in situ. Proc. Natl. Acad. Sci. USA 2006, 103, 9001-9005. [CrossRef] [PubMed]

100. Perumal, S.; Antipova, O.; Orgel, J.P.R.O. Collagen fibril architecture, domain organization, and triple-helical conformation govern its proteolysis. Proc. Natl. Acad. Sci. USA 2008, 105, 2824-2829. [CrossRef] [PubMed]

101. Shoulders, M.D.; Raines, R.T. Collagen structure and stability. Annu. Rev. Biochem. 2009, 78, 929-958. [CrossRef] [PubMed] 
102. Addadi, L.; Weiner, S. Interactions between acidic proteins and crystals: Stereochemical requirements in biomineralization. Proc. Natl. Acad. Sci. USA 1985, 82, 4110-4114. [CrossRef] [PubMed]

103. Mann, S.; Archibald, D.D.; Didymus, J.M.; Douglas, T.; Heywood, B.R.; Meldrum, F.C.; Reeves, N.J. Organic Interfaces: Biominerals. Science 1993, 261, 1286-1292. [CrossRef] [PubMed]

104. Berman, A.; Ahn, D.J.; Lio, A.; Salmeron, M.; Reichert, A.; Charych, D. Total alignment of calcite at acidic polydiacetylene films: Cooperativity at the organic-inorganic Interface. Science 1995, 269, 515-518. [CrossRef] [PubMed]

105. Aizenberg, J.; Black, A.J.; Whitesides, G.M. Oriented growth of calcite controlled by self-assembled monolayers of functionalized alkanethiols supported on gold and silver. J. Am. Chem. Soc. 1999, 121, 4500-4509. [CrossRef]

106. Travaille, A.M.; Kaptijn, L.; Verwer, P.; Hulsken, B.; Elemans, J.A.A.W.; Nolte, R.J.M.; Van Kempen, H. Highly oriented self-assembled monolayers as templates for epitaxial calcite growth. J. Am. Chem. Soc. 2003, 125, 11571-11577. [CrossRef] [PubMed]

107. Duffy, D.M.; Harding, J.H. Simulation of organic monolayers as templates for the nucleation of calcite crystals. Langmuir 2004, 20, 7630-7636. [CrossRef] [PubMed]

108. DiMasi, E.; Olszta, M.J.; Patel, V.M.; Gower, L.B. When is template directed mineralization really template directed? CrystEngComm 2003, 5, 346. [CrossRef]

109. Gehrke, N.; Nassif, N.; Pinna, N.; Antonietti, M.; Gupta, H.S.; Cölfen, H. Retrosynthesis of nacre via amorphous precursor particles. Chem. Mater. 2005, 17, 6514-6516. [CrossRef]

110. Nudelman, F.; Pieterse, K.; George, A.; Bomans, P.H.H.; Friedrich, H.; Brylka, L.J.; Hilbers, P.A.J.; de With, G.; Sommerdijk, N.A.J.M. The role of collagen in bone apatite formation in the presence of hydroxyapatite nucleation inhibitors. Nat. Mater. 2010, 9, 1004-1009. [CrossRef] [PubMed]

111. Niu, L.; Jee, S.E.; Jiao, K.; Tonggu, L.; Li, M.; Wang, L.; Yang, Y.; Bian, J.; Breschi, L.; Jang, S.S.; et al. Collagen intrafibrillar mineralization as a result of the balance between osmotic equilibrium and electroneutrality. Nat. Mater. 2016, 16, 370-378. [CrossRef] [PubMed]

112. Wang, J.; Chen, Y.; Li, L.; Sun, J.; Gu, X.; Xu, X.; Pan, H.; Tang, R. Remineralization of dentin collagen by meta-stabilized amorphous calcium phosphate. CrystEngComm 2013, 15, 6151-6158. [CrossRef]

113. Wang, Y.; Azaïs, T.; Robin, M.; Vallée, A.; Catania, C.; Legriel, P.; Pehau-Arnaudet, G.; Babonneau, F.; Giraud-Guille, M.-M.; Nassif, N. The predominant role of collagen in the nucleation, growth, structure and orientation of bone apatite. Nat. Mater. 2012, 11, 724-733. [CrossRef] [PubMed]

114. Liu, Y.; Kim, Y.K.; Dai, L.; Li, N.; Khan, S.O.; Pashley, D.H.; Tay, F.R. Hierarchical and non-hierarchical mineralisation of collagen. Biomaterials 2011, 32, 1291-1300. [CrossRef] [PubMed]

115. Liu, Y.; Li, N.; Qi, Y.P.; Dai, L.; Bryan, T.E.; Mao, J.; Pashley, D.H.; Tay, F.R. Intrafibrillar collagen mineralization produced by biomimetic hierarchical nanoapatite assembly. Adv. Mater. 2011, 23, 975-980. [CrossRef] [PubMed]

116. Dai, L.; Qi, Y.P.; Niu, L.N.; Liu, Y.; Pucci, C.R.; Looney, S.W.; Ling, J.Q.; Pashley, D.H.; Tay, F.R. Inorganic-organic nanocomposite assembly using collagen as a template and sodium tripolyphosphate as a biomimetic analog of matrix phosphoprotein. Cryst. Growth Des. 2011, 11, 3504-3511. [CrossRef] [PubMed]

117. Niu, L.N.; Jiao, K.; Ryou, H.; Yiu, C.K.Y.; Chen, J.H.; Breschi, L.; Arola, D.D.; Pashley, D.H.; Tay, F.R. Multiphase intrafibrillar mineralization of collagen. Angew. Chem.-Int. Ed. 2013, 52, 5762-5766. [CrossRef] [PubMed]

118. Zhang, W.; Luo, X.; Niu, L.; Yang, H.; Yiu, C.K.Y.; Wang, T.; Zhou, L.; Mao, J.; Huang, C.; Pashley, D.H.; et al. Biomimetic intrafibrillar mineralization of type i collagen with intermediate precursors-loaded mesoporous carriers. Sci. Rep. 2015, 5, 11199. [CrossRef] [PubMed]

119. Sun, J.; Chen, C.; Pan, H.; Chen, Y.; Mao, C.; Wang, W.; Tang, R.; Gu, X. Biomimetic promotion of dentin remineralization using l-glutamic acid: Inspiration from biomineralization proteins. J. Mater. Chem. B 2014, 2, 4544-4553. [CrossRef]

120. Chen, C.; Mao, C.; Sun, J.; Chen, Y.; Wang, W.; Pan, H.; Tang, R.; Gu, X. Glutaraldehyde-induced remineralization improves the mechanical properties and biostability of dentin collagen. Mater. Sci. Eng. C 2016, 67, 657-665. [CrossRef] [PubMed]

121. Ubukata, T. Architectural, constraints on the morphogenesis of prismatic structure in bivalvia. Palaeontology 1994, 37, 241-261. 
122. Checa, A.G.; Rodriguez-Navarro, A. Geometrical and crystallographic constraints determine the self-organization of shell microstructures in Unionidae (Bivalvia: Mollusca). Proc. R. Soc. B Biol. Sci. 2001, 268, 771-778. [CrossRef] [PubMed]

123. Gilbert, P.; Metzler, R.A.; Zhou, D.; Scholl, A.; Doran, A.; Young, A.; Kunz, M.; Tamura, N.; Coppersmith, S.N. Gradual ordering in red abalone nacre. J. Am. Chem. Soc. 2008, 130, 17519-17527. [CrossRef] [PubMed]

124. Ping, H.; Xie, H.; Wan, Y.; Zhang, Z.; Zhang, J.; Xiang, M.; Xie, J.; Wang, H.; Wang, W.; Fu, Z. Confinement controlled mineralization of calcium carbonate within collagen fibrils. J. Mater. Chem. B 2016, 4, 880-886. [CrossRef]

125. Cantaert, B.; Beniash, E.; Meldrum, F.C. Nanoscale confinement controls the crystallization of calcium phosphate: Relevance to bone formation. Chemistry 2013, 19, 14918-14924. [CrossRef] [PubMed]

126. Xiao, C.; Li, M.; Wang, B.; Liu, M.-F.; Shao, C.; Pan, H.; Lu, Y.; Xu, B.-B.; Li, S.; Zhan, D.; et al. Total morphosynthesis of biomimetic prismatic-type $\mathrm{CaCO}_{3}$ thin films. Nat. Commun. 2017, 8, 1398. [CrossRef] [PubMed]

127. Gower, L.B.; Odom, D.J. Deposition of calcium carbonate films by a polymer-induced liquid-precursor (PILP) process. J. Cryst. Growth 2000, 210, 719-734. [CrossRef]

128. Wei, H.; Ma, N.; Shi, F.; Wang, Z.; Zhang, X. Artificial nacre by alternating preparation of layer-by-layer polymer films and $\mathrm{CaCO}_{3}$ strata. Chem. Mater. 2007, 19, 1974-1978. [CrossRef]

129. Finnemore, A.; Cunha, P.; Shean, T.; Vignolini, S.; Guldin, S.; Oyen, M.; Steiner, U. Biomimetic layer-by-layer assembly of artificial nacre. Nat. Commun. 2012, 3, 966. [CrossRef] [PubMed]

130. Mao, L.-B.; Gao, H.-L.; Yao, H.-B.; Liu, L.; Colfen, H.; Liu, G.; Chen, S.-M.; Li, S.-K.; Yan, Y.-X.; Liu, Y.-Y.; et al. Synthetic nacre by predesigned matrix-directed mineralization. Science 2016, 354, 107-110. [CrossRef] [PubMed]

131. Xu, X.; Han, J.T.; Cho, K. Formation of amorphous calcium carbonate thin films and their role in biomineralization. Chem. Mater. 2004, 16, 1740-1746. [CrossRef]

132. Jiang, J.; Gao, M.-R.; Qiu, Y.-H.; Wang, G.-S.; Liu, L.; Cai, G.-B.; Yu, S.-H. Confined crystallization of polycrystalline high-magnesium calcite from compact $\mathrm{Mg}$-ACC precursor tablets and its biological implications. CrystEngComm 2011, 13, 952-956. [CrossRef]

133. Rajasekharan, A.K.; Andersson, M. Role of nanoscale confinement on calcium phosphate formation at high supersaturation. Cryst. Growth Des. 2015, 15, 2775-2780. [CrossRef]

134. Loste, E.; Meldrum, F.C. Control of calcium carbonate morphology by transformation of an amorphous precursor in a constrained volume. Chem. Commun. 2001, 10, 901-902. [CrossRef]

135. Park, R.J.; Meldrum, F.C. Synthesis of single crystals of calcite with complex morphologies. Adv. Mater. 2002, 14, 1167-1169. [CrossRef]

136. Loste, E.; Park, R.J.; Warren, J.; Meldrum, F.C. Precipitation of calcium carbonate in confinement. Adv. Funct. Mater. 2004, 14, 1211-1220. [CrossRef]

137. Stephens, C.J.; Ladden, S.F.; Meldrum, F.C.; Christenson, H.K. Amorphous calcium carbonate is stabilized in confinement. Adv. Funct. Mater. 2010, 20, 2108-2115. [CrossRef]

138. He, G.; Dahl, T.; Veis, A.; George, A. Nucleation of apatite crystals in vitro by self-assembled dentin matrix protein 1. Nat. Mater. 2003, 2, 552-558. [CrossRef] [PubMed]

139. Cölfen, H. Biomineralization: A crystal-clear view. Nat. Mater. 2010, 9, 960-961. [CrossRef] [PubMed]

140. Dimasi, E.; Kwak, S.Y.; Amos, F.F.; Olszta, M.J.; Lush, D.; Gower, L.B. Complementary control by additives of the kinetics of amorphous $\mathrm{CaCO}_{3}$ mineralization at an organic interface: In-situ synchrotron X-ray observations. Phys. Rev. Lett. 2006, 97, 1-4. [CrossRef] [PubMed]

141. Cheng, X.; Varona, P.L.; Olszta, M.J.; Gower, L.B. Biomimetic synthesis of calcite films by a polymer-induced liquid-precursor (PILP) process. 1. Influence and incorporation of magnesium. J. Cryst. Growth 2007, 307, 395-404. [CrossRef]

142. Homeijer, S.J.; Olszta, M.J.; Barrett, R.A.; Gower, L.B. Growth of nanofibrous barium carbonate on calcium carbonate seeds. J. Cryst. Growth 2008, 310, 2938-2945. [CrossRef]

143. Olszta, M.J.; Gajjeraman, S.; Kaufman, M.; Gower, L.B. Nanofibrous calcite synthesized via a solution-precursor-solid mechanism. Chem. Mater. 2004, 16, 2355-2362. [CrossRef]

144. Bergström, L.; Sturm, E.V.; Salazar-Alvarez, G.; Cölfen, H. Mesocrystals in biominerals and colloidal arrays. Acc. Chem. Res. 2015, 48, 1391-1402. 
145. Revealed, I.; Yuwono, V.M.; Burrows, N.D.; Soltis, J.A.; Lee Penn, R. Oriented aggregation: Formation and transformation of mesocrystal. J. Am. Chem. Soc. 2010, 132, 2163-2165.

146. Niederberger, M.; Cölfen, H. Oriented attachment and mesocrystals: Non-classical crystallization mechanisms based on nanoparticle assembly. Phys. Chem. Chem. Phys. 2006, 8, 3271-3287. [CrossRef] [PubMed]

147. Cölfen, H.; Antonietti, M. Mesocrystals: Inorganic superstructures made by highly parallel crystallization and controlled alignment. Angew. Chem.-Int. Ed. 2005, 44, 5576-5591. [CrossRef] [PubMed]

148. Long, X.; Ma, Y.; Cho, K.R.; Li, D.; De Yoreo, J.J.; Qi, L. Oriented calcite micropillars and prisms formed through aggregation and recrystallization of poly(acrylic acid) stabilized nanoparticles. Cryst. Growth Des. 2013, 13, 3856-3863. [CrossRef]

149. Agthe, M.; Plivelic, T.S.; Labrador, A.; Bergström, L.; Salazar-Alvarez, G. Following in real time the two-step assembly of nanoparticles into mesocrystals in levitating drops. Nano Lett. 2016, 16, 6838-6843. [CrossRef] [PubMed]

150. Zhu, G.; Yao, S.; Zhai, H.; Liu, Z.; Li, Y.; Pan, H.; Tang, R. Evolution from classical to non-classical aggregation-based crystal growth of calcite by organic additive control. Langmuir 2016, 32, 8999-9004. [CrossRef] [PubMed]

151. Kim, Y.-Y.; Schenk, A.S.; Ihli, J.; Kulak, A.N.; Hetherington, N.B.J.; Tang, C.C.; Schmahl, W.W.; Griesshaber, E.; Hyett, G.; Meldrum, F.C. A critical analysis of calcium carbonate mesocrystals. Nat. Commun. 2014, 5, 1-14. [CrossRef] [PubMed]

152. Tao, J.; Pan, H.; Zeng, Y.; Xu, R.; Tang, R. Roles of amorphous calcium phosphate and biological additives in the assembly of hydroxyapatite nanoparticles. J. Phys. Chem. B 2007, 111, 13410-13418. [CrossRef] [PubMed]

153. Zhai, H.; Jiang, W.; Tao, J.; Lin, S.; Chu, X.; Xu, X.; Tang, R. Self-assembled organic-inorganic hybrid elastic crystal via biomimetic mineralization. Adv. Mater. 2010, 22, 3729-3734. [CrossRef] [PubMed]

154. Zhai, H.; Quan, Y.; Li, L.; Liu, X.-Y.; Xu, X.; Tang, R. Spontaneously amplified homochiral organic-inorganic nano-helix complexes via self-proliferation. Nanoscale 2013, 5, 3006-3012. [CrossRef] [PubMed]

155. Tao, J.; Zhou, D.; Zhang, Z.; Xu, X.; Tang, R. Magnesium-aspartate-based crystallization switch inspired from shell molt of crustacean. Proc. Natl. Acad. Sci. USA 2009, 106, 22096-22101. [CrossRef] [PubMed]

156. Orme, C.A.; Noy, A; Wierzbicki, A; McBride, M.T.; Grantham, M.; Teng, H.H.; Dove, P.M.; DeYoreo, J.J. Formation of chiral morphologies through selective binding of amino acids to calcite surface steps. Nature 2001, 411, 775-779. [CrossRef] [PubMed]

157. Chung, J.; Granja, I.; Taylor, M.G.; Mpourmpakis, G.; Asplin, J.R.; Rimer, J.D. Molecular modifiers reveal a mechanism of pathological crystal growth inhibition. Nature 2016, 536, 446-450. [CrossRef] [PubMed]

158. De Yoreo, J.J.; Zepeda-Ruiz, L.A.; Friddle, R.W.; Qiu, S.R.; Wasylenki, L.E.; Chernov, A.A.; Gilmer, G.H.; Dove, P.M. Rethinking classical crystal growth models through molecular scale insights: Consequences of kink-limited kinetics. Cryst. Growth Des. 2009, 9, 5135-5144. [CrossRef]

159. Yang, X.; Xie, B.; Wang, L.; Qin, Y.; Henneman, Z.J.; Nancollas, G.H. Influence of magnesium ions and amino acids on the nucleation and growth of hydroxyapatite. CrystEngComm 2011, 13, 1153-1158. [CrossRef]

160. Song, R.-Q.; Cölfen, H. Additive controlled crystallization. CrystEngComm 2011, 13, 1249. [CrossRef]

161. Qiu, S.R.; Orme, C. A Dynamics of biomineral formation at the near molecular level. Chem. Rev. 2008, 108, 4784-4822. [CrossRef] [PubMed]

162. Giocondi, J.L.; El-Dasher, B.S.; Nancollas, G.H.; Orme, C.A. Molecular mechanisms of crystallization impacting calcium phosphate cements. Philos. Trans. R. Soc. A Math. Phys. Eng. Sci. 2010, 368, 1937-1961. [CrossRef] [PubMed]

163. Sikirić, M.D.; Füredi-Milhofer, H. The influence of surface active molecules on the crystallization of biominerals in solution. Adv. Colloid Interface Sci. 2006, 128-130, 135-158. [CrossRef] [PubMed]

164. Nancollas, G.H.; Wu, W. Biomineralization mechanisms: A kinetics and interfacial energy approach. J. Cryst. Growth 2000, 211, 137-142. [CrossRef]

165. Liu, X.Y. From solid-fluid interfacial structure to nucleation kinetics: principles and strategies for micro/nanostructure engineering. In Nanoscale Structure and Assembly at Solid-Fluid Interfaces: Interfacial Structures versus Dynamics; Liu, X.Y., De Yoreo, J., Eds.; Springer: London, UK, 2004; Volume 1, pp. 109-175, ISBN 978-1-4020-7810-1.

166. Demichelis, R.; Raiteri, P.; Gale, J.D.; Quigley, D.; Gebauer, D. Stable prenucleation mineral clusters are liquid-like ionic polymers. Nat. Commun. 2011, 2, 590. [CrossRef] [PubMed] 
167. Cheng, Y.-T.; Johnson, W.L. Disordered Materials: A Survey of Amorphous Solids. Science 1987, 235, 997-1002. [CrossRef] [PubMed]

168. Betts, F.; Posner, A. Structural model for amorphous calcium phosphate. Trans. Am. Crystallogr. Assoc. 1974, $10,73-84$.

169. Betts, F.; Posner, A.S. An X-ray radial distribution study of amorphous calcium phosphate. Mater. Res. Bull. 1974, 9, 353-360. [CrossRef]

170. Treboux, G.; Layrolle, P.; Kanzaki, N.; Onuma, K.; Ito, A. Existence of Posner's Cluster in Vacuum. J. Phys. Chem. A 2000, 104, 5111-5114. [CrossRef]

171. Kanzaki, N.; Treboux, G.; Onuma, K.; Tsutsumi, S.; Ito, A. Calcium phosphate clusters. Biomaterials 2001, 22, 2921-2929. [CrossRef]

172. Dorozhkin, S.V. Calcium orthophosphates. J. Mater. Sci. 2007, 42, 1061-1095. [CrossRef]

173. Sedlak, J.M.; Beebe, R.A. Temperature programmed dehydration of amorphous calcium phosphate. J. Colloid Interface Sci. 1974, 47, 483-489. [CrossRef]

174. Kojima, Y.; Sakama, K.; Toyama, T.; Yasue, T.; Arai, Y. Dehydration of water molecules in amorphous calcium phosphate. Phosphorus Res. Bull. 1994, 4, 47-52. [CrossRef]

175. Eanes, E.D.; Posner, A. Division of biophysics: Kinetics and mechanism of conversion of noncrystalline calcium phosphate to crystalline hydroxyapatite. Trans. N. Y. Acad. Sci. 1965, 28, 233-241. [CrossRef]

176. Blumenthal, N.C.; Posner, A.S.; Holmes, J.M. Effect of preparation conditions on the properties and transformation of amorphous calcium phosphate. Mater. Res. Bull. 1972, 7, 1181-1189. [CrossRef]

177. Termine, J.D.; Posner, A.S. Infra-red determination of the percentage of crystallinity in apatitic calcium phosphates. Nature 1966, 211, 268-270. [CrossRef] [PubMed]

178. Harries, J.E.; Hukins, D.W.L.; Holt, C.; Hasnain, S.S. Conversion of amorphous calcium phosphate into hydroxyapatite investigated by EXAFS spectroscopy. J. Cryst. Growth 1987, 84, 563-570. [CrossRef]

179. Feng, C.F.; Khor, K.A.; Kweh, S.W.K.; Cheang, P. Thermally induced crystallization of amorphous calcium phosphate in plasma-spheroidised hydroxyapatite powders. Mater. Lett. 2000, 46, 229-233. [CrossRef]

180. Jaeger, C.; Maltsev, S.K.A. Progress of structural elucidation of amorphous calcium phosphate (ACP) and hydroxyapatite (HAP): Disorder and surfaces as seen by solid state NMR. Key Eng. Mater. 2006, 69-72. [CrossRef]

181. Rodriguez-Blanco, J.D.; Shaw, S.; Benning, L.G. The kinetics and mechanisms of amorphous calcium carbonate (ACC) crystallization to calcite, viavaterite. Nanoscale 2011, 3, 265-271. [CrossRef] [PubMed]

182. Hu, Q.; Nielsen, M.H.; Freeman, C.L.; Hamm, L.M.; Tao, J.; Lee, J.R.I.; Han, T.Y.J.; Becker, U.; Harding, J.H.; Dove, P.M.; et al. The thermodynamics of calcite nucleation at organic interfaces: Classical vs. non-classical pathways. Faraday Discuss. 2012, 159, 509-523. [CrossRef]

183. Hamm, L.M.; Giuffre, A.J.; Han, N.; Tao, J.; Wang, D.; De Yoreo, J.J.; Dove, P.M. Reconciling disparate views of template-directed nucleation through measurement of calcite nucleation kinetics and binding energies. Proc. Natl. Acad. Sci. USA 2014, 111, 1304-1309. [CrossRef] [PubMed]

184. Jahromi, M.T.; Yao, G.; Cerruti, M. The importance of amino acid interactions in the crystallization of hydroxyapatite. J. R. Soc. Interface 2013, 10, 20120906. [CrossRef] [PubMed]

185. Liu, Z.; Xu, X.; Tang, R. Improvement of Biological Organisms Using Functional Material Shells. Adv. Funct. Mater. 2016, 26, 1862-1880. [CrossRef]

186. Satyanarayana, T.; Prakash, A.; Johri, B.N. Microorganisms in environmental management: Microbes and environment. In Microorg. Environ. Manag. Microbes Environ; Springer Science \& Business Media Press: Kluwer, The Netherlands, 2012.

187. Smeets, P.J.M.; Cho, K.R.; Kempen, R.G.E.; Sommerdijk, N.A.J.M.; De Yoreo, J.J. Calcium carbonate nucleation driven by ion binding in a biomimetic matrix revealed by in situ electron microscopy. Nat. Mater. 2015, 14, 394-399. [CrossRef] [PubMed]

188. Xu, X.; Han, J.T.; Kim, D.H.; Cho, K. Two modes of transformation of amorphous calcium carbonate films in air. J. Phys. Chem. B 2006, 110, 2764-2770. [CrossRef] [PubMed]

189. Ihli, J.; Kulak, A.N.; Meldrum, F.C. Freeze-drying yields stable and pure amorphous calcium carbonate (ACC). Chem. Commun. 2013, 49, 3134-3136. [CrossRef] [PubMed]

190. De Yoreo, J. Research Methods in Biomineralization Science; Elsevier Press: Amsterdam, The Netherlands, 2013.

191. Stephenson, A.E.; DeYoreo, J.J.; Wu, L.; Wu, K.J.; Hoyer, J.; Dove, P.M. Peptides enhance magnesium signature in calcite: Insights into origins of vital effects. Science 2008, 322, 724-727. [CrossRef] [PubMed] 
192. Li, Q.; Csetenyi, L.; Gadd, G.M. Biomineralization of metal carbonates by Neurospora crassa. Environ. Sci. Technol. 2014, 48, 14409-14416. [CrossRef] [PubMed]

193. Cai, G.-B.; Zhao, G.-X.; Wang, X.-K.; Yu, S.-H. Synthesis of polyacrylic acid stabilized amorphous calcium carbonate nanoparticles and their application for removal of toxic heavy metal ions in water. J. Phys. Chem. C 2010, 114, 12948-12954. [CrossRef]

194. Xiong, W.; Tang, Y.; Shao, C.; Zhao, Y.; Jin, B.; Huang, T.; Miao, Y.; Shu, L.; Ma, W.; Xu, X. Prevention of cyanobacterial blooms using nanosilica: A biomineralization-inspired strategy. Environ. Sci. Technol. 2017, 51, 12717-12726. [CrossRef] [PubMed]

195. Nam, K.T.; Kim, D.-W.; Yoo, P.J.; Chiang, C.-Y.; Meethong, N.; Hammond, P.T.; Chiang, Y.-M.; Belcher, A.M. Virus-enabled synthesis and assembly of nanowires for lithium ion battery electrodes. Science 2006, 312, 885-888. [CrossRef] [PubMed]

196. Uchiyama, H.; Hosono, E.; Zhou, H.; Imai, H. Three-dimensional architectures of spinel-type $\mathrm{LiMn}_{2} \mathrm{O}_{4}$ prepared from biomimetic porous carbonates and their application to a cathode for lithium-ion batteries. J. Mater. Chem. 2009, 19, 4012-4016. [CrossRef]

197. Ryu, J.; Kim, S.W.; Kang, K.; Park, C.B. Mineralization of self-assembled peptide nanofibers for rechargeable lithium ion batteries. Adv. Mater. 2010, 22, 5537-5541. [CrossRef] [PubMed]

198. Xiong, W.; Zhao, X.; Zhu, G.; Shao, C.; Li, Y.; Ma, W.; Xu, X.; Tang, R. Silicification-induced cell aggregation for the sustainable production of $\mathrm{H}_{2}$ under aerobic conditions. Angew. Chem. 2015, 127, 12129-12133. [CrossRef]

199. Yao, S.; Jin, B.; Liu, Z.; Shao, C.; Zhao, R.; Wang, X.; Tang, R. Biomineralization: From material tactics to biological strategy. Adv. Mater. 2017, 29. [CrossRef] [PubMed]

200. Wang, X.; Sun, C.; Li, P.; Wu, T.; Zhou, H.; Yang, D.; Liu, Y.; Ma, X.; Song, Z.; Nian, Q.; et al. Vaccine engineering with dual-functional mineral shell: A promising strategy to overcome preexisting immunity. Adv. Mater. 2016, 28, 694-700. [CrossRef] [PubMed]

201. Wang, G.; Li, X.; Mo, L.; Song, Z.; Chen, W.; Deng, Y.; Zhao, H.; Qin, E.; Qin, C.; Tang, R. Eggshell-inspired biomineralization generates vaccines that do not require refrigeration. Angew. Chem.-Int. Ed. 2012, 51, 10576-10579. [CrossRef] [PubMed]

202. Wang, B.; Liu, P.; Liu, Z.; Pan, H.; Xu, X.; Tang, R. Biomimetic construction of cellular shell by adjusting the interfacial energy. Biotechnol. Bioeng. 2014, 111, 386-395. [CrossRef] [PubMed] 